\title{
Antiviral Peptides: Identification and Validation
}

\author{
Garima Agarwal $^{1} \cdot$ Reema Gabrani $^{1}$ (])
}

Received: 13 February 2020 / Revised: 30 April 2020 / Accepted: 8 May 2020 / Published online: 18 May 2020

(c) Springer Nature B.V. 2020

\begin{abstract}
Despite rapid advances in the human healthcare, the infection caused by certain viruses results in high morbidity and mortality accentuate the importance for development of new antivirals. The existing antiviral drugs are limited, due to their inadequate response, increased rate of resistance and several adverse side effects. Therefore, one of the newly emerging field "peptide-based therapeutics" against viruses is being explored and seems promising. Over the last few years, a lot of scientific effort has been made for the identification of novel and potential peptide-based therapeutics using various advanced technologies. Consequently, there are more than 60 approved peptide drugs available for sale in the market of United States, Europe, Japan, and some Asian countries. Moreover, the number of peptide drugs undergoing the clinical trials is rising gradually year by year. The peptide-based antiviral therapeutics have been approved for the Human immunodeficiency virus (HIV), Influenza virus and Hepatitis virus (B and C). This review enlightens the various peptide sources and the different approaches that have contributed to the search of potential antiviral peptides. These include computational approaches, natural and biological sources (library based high throughput screening) for the identification of lead peptide molecules against their target. Further the applications of few advanced techniques based on combinatorial chemistry and molecular biology have been illustrated to measure the binding parameters such as affinity and kinetics of the screened interacting partners. The employment of these advanced techniques can contribute to investigate antiviral peptide therapeutics for emerging infections.
\end{abstract}

Keywords Binding evaluation techniques $\cdot$ High throughput screening methods $\cdot$ In silico approaches $\cdot$ Peptide based therapeutics

\section{Introduction}

The infections caused by viral pathogens including clinical viruses or naturally emerging viruses pose a serious threat worldwide. Unfortunately, only few therapeutics are available for limited viruses like Human immunodeficiency virus (HIV), Hepatitis virus, Herpes simplex virus (HSV) and Influenza virus (Rider et al. 2011). Researchers are currently working to extend the range of specific and novel antivirals to other families of pathogens. Since, viruses depend on host cell organism for replication, the selection of target for the designing of effective and safe antiviral drugs without harming the host cell, is an extremely difficult process. Besides this, owing to the evolution, mutations occur in the

Reema Gabrani

reema.gabrani@jiit.ac.in

1 Department of Biotechnology, Center for Emerging Diseases, Jaypee Institute of Information Technology, Noida, UP 201309, India viral genome, which contribute to the development of resistance to drugs and thus rendered many drugs ineffective (Lee et al. 2019). The peptides can block infection by targeting either virus or its host. The virus specific antiviral peptides are known as virucidal, as they directly target the viral proteins. Most of the antivirals have been reported to inhibit the development of viruses by targeting its specific regions or components. Various steps of viral life cycle have been targeted for the discovery of novel antiviral drugs, such as viral entry, viral synthesis, or assembly. Due to the extracellular site of action and blockage of viral infection, the viral entry inhibition is marked as an attractive strategy (Chew et al. 2017). Protein-protein interactions (PPIs) are the foundation of important cellular processes and are considered as primary targets for the drug discovery over the last decade (Lee et al. 2019; Teissier et al. 2011). The knowledge of crucial interactors involved in PPIs and their mechanism is necessary to pave way for the selection of suitable target for drug discovery. New approaches in therapeutics include the use of small cyclic molecules, proteins/peptides, nucleic 
acids such as small interfering RNA (siRNA) and small hairpin RNA (shRNA) molecules (Teissier et al. 2011). Among these advanced approaches, peptides as therapeutics is a promising field in the drug discovery (Lau and Dunn 2018). Peptides are the biologically active molecules composed of amino acids residues that disrupt the PPIs. They are small (less than 100 amino acids), and they can be easily synthesized. They are also highly specific and effective even in nanomolar range. The main benefit of using peptide as therapeutics is its hydrolysis by peptidases present in the body, which prevents its accumulation in specific organs and minimizes the toxic side effects (Ali et al. 2013). Previously, the pharmaceutical industries have shown poor interest for the expansion of peptide-based therapeutics because of their extremely poor ADME (absorption, distribution, metabolism and elimination) properties. However, the advanced research enables modifications of the peptides such as synthesis of amino acid enantiomers, addition of chemical compounds and their nanoparticle formulation to overcome the pharmacodynamic flaws of peptides (Gentilucci et al. 2010; Zeng et al. 2018). The advantages offered by the modified peptides have sparked the interest amongst the researchers and companies. Now-a-days peptide as therapeutics has come to forte with nearly 20 new peptides added in clinical trials annually. In fact, the global market of peptides as drugs has reached to billion dollars with currently more than 60 peptides approved by US Food and Drug Administration (FDA) and over 400 peptides being under clinical phase trials (Lau and Dunn 2018). Peptide as therapeutics are approved or are being considered for the treatment of diseases such as cancer, diabetes, cardiovascular diseases and even infection caused by few viruses such as HIV, Herpes, Hepatitis and Influenza virus. Thus, over the years peptide-based therapeutics has added a new dimension as the potential antiviral candidate. This review focuses on the types of peptides approaches that can be used for the identification of the lead peptides against the target protein and the selected advanced techniques reported for the validation of the peptide binding affinity to their targets.

\section{Antiviral Peptides as Therapeutics}

The peptides possessing potential to inhibit the virus are considered as antiviral peptides (AVPs). Usually, the AVPs exhibit antiviral effects by inhibiting the virus directly, but their inhibition sites and the mechanism of action vary within the viral replication cycle (Rider et al. 2011). The AVPs can be obtained through different approaches: (1) Computational approach (2) Natural sources and (3) Biological source such as High-throughput screening (Fig. 1). There are many online databases available which contain information regarding experimentally tested antiviral peptides such

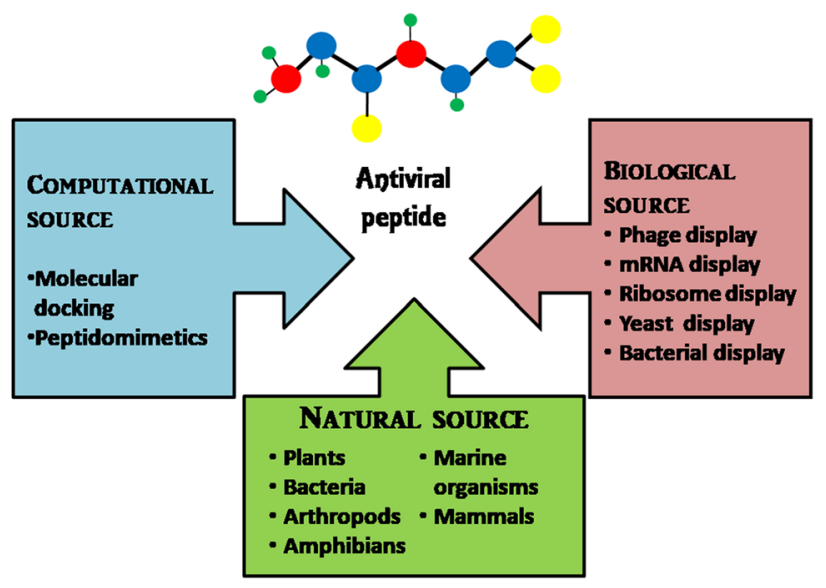

Fig. 1 Different sources of antiviral peptides

as Antiviral peptide database (AVPdp) (Qureshi et al. 2013) where 2683 entries of peptides including 624 modified AVPs are compiled till December 2019, while many others are unreported. Since the field of peptides as antiviral is not entirely explored, therefore, many research studies are being undertaken to elucidate the role of peptides in blocking viral infections. The first peptide drug approved for clinical indication, Enfuvirtide (Enf), a 36-amino acid residue peptide, against HIV corresponds to the heptad-repeat (HR2) domain of gp41 (HIV envelope protein). Enf prevents the fusion of HR1 domain to HR2 during HIV formation and blocks HIV infection (Teissier et al. 2011). Similarly, Boceprevir and Telaprevir, both synthetic peptides against Hepatitis $C$ virus (HCV), got approval by FDA in 2011. These peptides act on NS3/4, a protease inhibitor, and interfere with viral replication (Divyashree et al. 2020). Other peptide candidates such as Myrcludex for Hepatitis B and D viruses (HBV and HDV) (Bogomolov et al. 2016), Flufirvitide for Influenza virus (Skalickova et al. 2015), Sifuvirtide for HIV-1 (Yu et al. 2018), IM862 and SCV-07 for HCV and Thymosin $\alpha-1$ for HBV as well as HCV (Jenssen 2009), are under various phase trials of pre-clinical and clinical studies. We have discussed the different approaches used for the identification of AVPs. Moreover, the few selected methodologies used for the validation of identified peptides as potential AVPs have also been described here. The techniques used in identification and validation of peptides are compared in Table 1.

\section{Antiviral Peptides Designed from Computational Approach}

Computer assisted drug designing process is based on the understanding of structural and functional aspects of the viral machinery. The rational knowledge of the viral proteins and the interactors/cellular partners assists in the selection of target protein. This approach has expedited the process of 


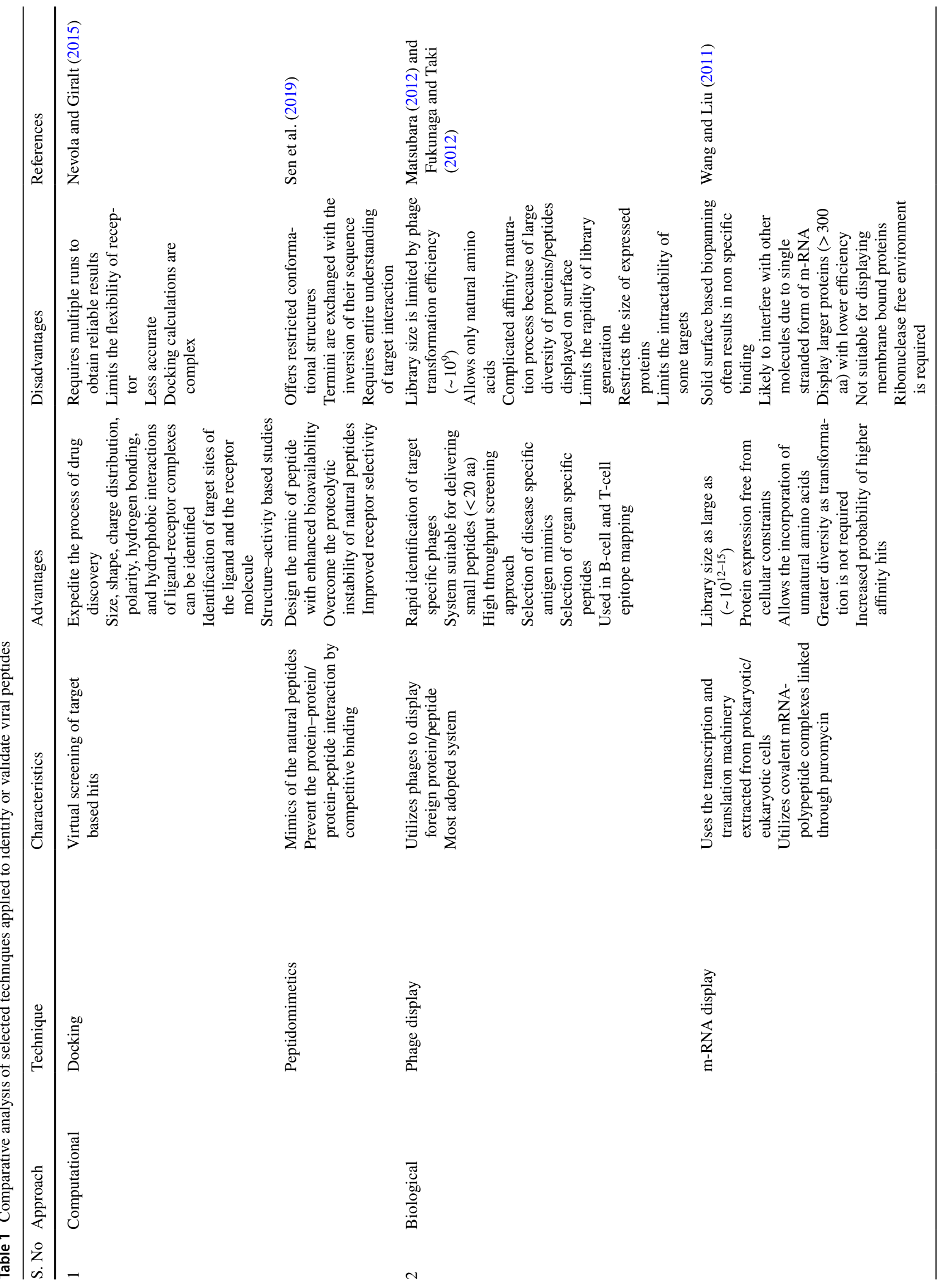




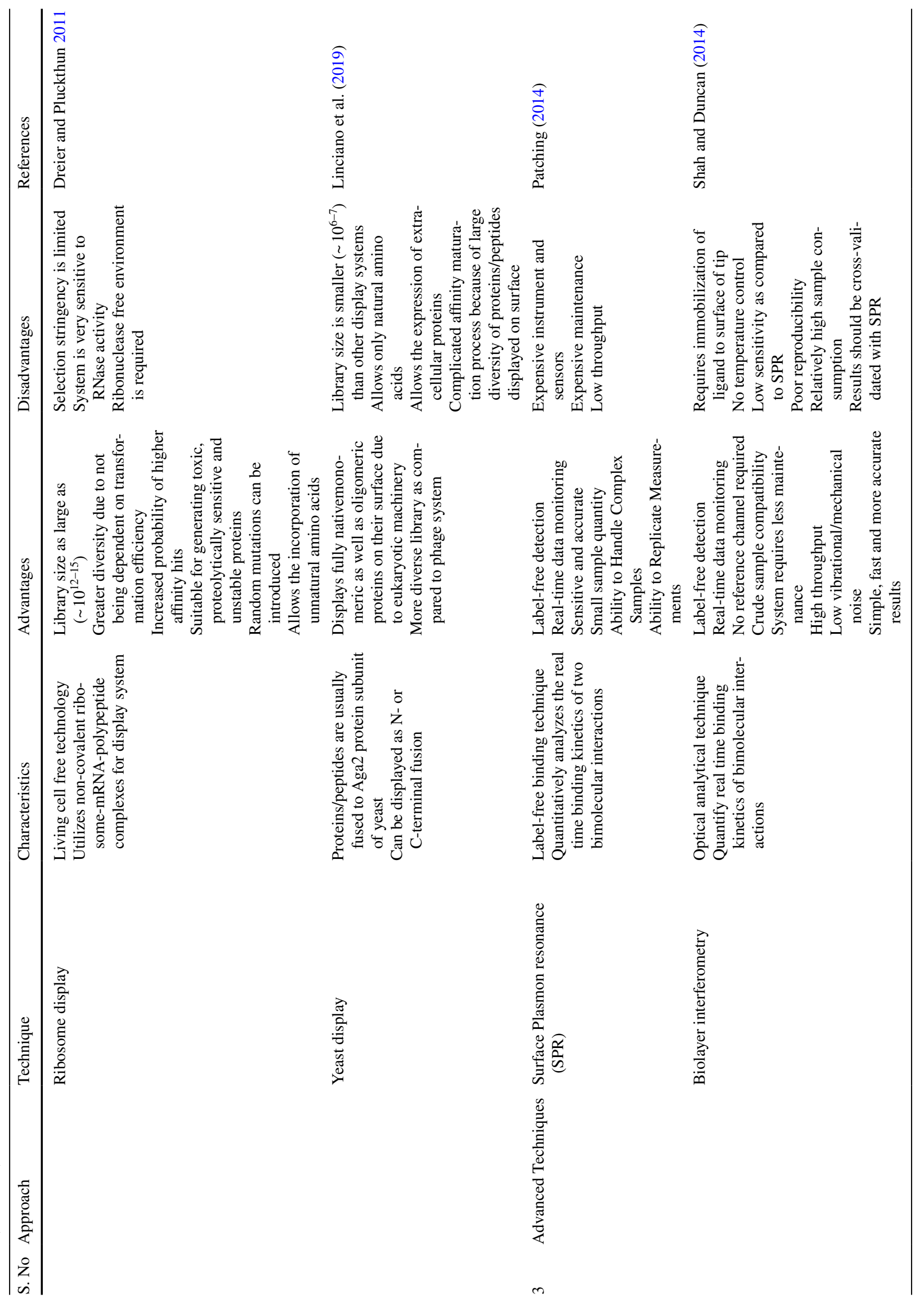


drug designing. Peptides can be identified computationally; via in silico screening using molecular docking. A docking program predicts the target site which is usually known as pocket or protrusion with hydrogen bond donors and acceptors, hydrophobic characteristics and different molecular shapes. Subsequently, library of peptides docked with these pockets results in the highest binding peptide (Nevola and Giralt 2015). For example, peptides have been designed computationally using virtual docking against the surface protein of Zika virus (ZIKV) for its detection. Tetra, penta, hexa and heptapeptide libraries were docked using Open Eye Scientific Software against envelope protein of ZIKV; subsequently, eight peptides were selected. They were further tested by Direct ELISA and out of them, three were delineated with best performance for Zika detection (Mascini et al. 2019). Another method is based on peptidomimetics which mimics the designed targets, prevents the interaction of proteins by competitive binding. Four putative peptide inhibitors were designed against Nipah virus (NiV) proteins using the approach of peptidomimetics and the stability of peptide-protein complexes were analysed using MD simulation (Sen et al. 2019). The in silico methods (Docking and peptidomimetics) can predict the peptide sequence but further validation using in vitro/in vivo approaches is required to establish its biological activity.

\section{Antiviral Peptides Derived from Natural Source}

The peptides that exhibit immunomodulatory and inhibitory properties against infection caused by bacteria, fungi, viruses or protozoa, are expressed as naturally occurring antimicrobial peptides (AMPs). The AMPs have been extensively used as substitutes of antibiotics for bacterial infections, but recently their use has been expanded to antiviral therapeutics also (Ahmed et al. 2019a). The naturally occurring AVPs are amphipathic and cationic in nature with net positive charge (Bulet et al. 2004). Moreover, it has been proven that the hydrophobicity of the peptides is an essential property for targeting enveloped viruses (Badani et al. 2014; Wang et al. 2017). These AVPs can be derived from different sources such as plants, bacteria, arthropods, amphibians, marine organisms and mammals with their varied mechanism of action (Zhang and Gallo 2016). A peptide family called cyclotides derived from different plant sources has been proven successfully for their antiviral activity against HIV, Influenza virus and Dengue virus (Ireland et al. 2008; Sencanski et al. 2015; Gao et al. 2010). The small size, cationic and amphipathic nature of the cyclotides facilitates its effective binding to the target and rupture the membrane. This allows the leakage of cell components which further leads to the cell death (Weidmann and Craik 2016). In a study, kalata B1, a cyclotide isolated from the leaves of Oldenlandia affins plant, showed destruction of viral particle 
at entry step along with inhibition of viral-host membrane fusion, thus exhibiting anti-HIV activity (Henriques et al. 2011). Similarly, a peptide derived from arthropod, Hyalophora ceecropia, known as cecropin A showed the inhibitory activity against HIV, Junin virus (JUNV) and HSV by suppression of their gene expression (Wachinger et al. 1998; Albiol Matanic and Castilla 2004). Moreover, in recent studies bovine lactoferrin (bLF) has showed the antiviral activity against three Aedes mosquito transmitted viruses: Dengue (DENV), Chikungunya (CHIKV) and Zika virus apart from anti-HBV activity established in a previous study ( $\mathrm{Li}$ et al. 2009; Carvalho et al. 2017; Chen et al. 2017). The bLF blocks the viral binding to its target site and thus prevents its spread to host cells. Many other AVPs originated from natural source are summarized in Table 2 with their varied mode of action. However, despite promising efficacy, the utility of these peptides is constrained due to weak binding, low stability, other side effects and virus resistance. The shortcomings of AVPs from natural resource need to be addressed so that they can be considered as mainstay antiviral therapeutics.

\section{Antiviral Peptides Identified Through Biological Approach}

Methodologies based on in vitro display approach, usually offer genetically encoded peptides with superior quality and high affinity to their targets. Among these methodologies, phage display, mRNA display, ribosome display, yeast display and bacteria display are the most common technologies to generate peptides. The phage display technology is widely used and considered as the most appropriate for the screening of high efficiency peptides. While these technologies have already been thoroughly illustrated in other reviews (Nevola and Giralt 2015), we have focused on the use of selected methodologies for the identification of antiviral peptides and compared them in Table 1.

\section{Phage Display}

Phage display technology is an efficient in vitro screening method for the selection of high affinity and target specific peptide binder from a randomly displayed peptide library. The technology involves the fusion of exogenous peptide sequence into the genome of phage, its expression on the surface as fusion product to phage surface protein. The phage displayed libraries thus constructed have $10^{9-10}$ variants at a time. In this method, biopanning is performed in which the target molecule is immobilized on surface and incubated with phage library. The unbound or excess of phage particles are removed by washing and potentially bound phages are eluted by acidic/basic buffer or with appropriate ligand. These recovered phages are amplified by infecting bacterial cells Escherichia coli and are used for subsequent rounds of biopanning to obtain target specific phages using affinity selection. The sequencing of DNA isolated from binding phage, validated by ELISA, helps to identify peptide sequence (Fukunaga and Taki 2012; Matsubara 2012). A peptide named P3 against Japanese encephalitis virus (JEV) host fusion has been identified as the potential AVP using phage display library. The screened peptide has shown the highest affinity to domain III of JEV envelope glycoprotein assessed by Biolayer interferometry and $\mathrm{IC}_{90}$ of $\sim 100 \mu \mathrm{M}$ and $\mathrm{IC}_{50}$ of $\sim 1 \mu \mathrm{M}$ in JEV infected BHK-21 cells (Wei et al. 2019). Similarly, an analogous study conducted by de la Guardia et al. (2017) identified three peptides against the domain III of DENV envelope protein to block the DENV infection. Further these peptides were non-toxic to the target cells. Moreover, the same approach has also been used to identify peptides targeting non-structural viral protein: RNA-dependent RNA polymerase (NS5B) of HCV, by screening a library composed of disulfide-constrained heptapeptides (Amin et al. 2003). In another study, a novel heptapeptide was identified using random peptide phage library which inhibited the integration of HIV genome into the host (Desjobert et al. 2004). The most important advantage of this technology over others is its high rate of mutability with affinity selection, which widely employs the screening of phage displayed peptides for identification of potential AVPs. There are many other AVPs derived from the utilization of phage display technology which are summarised in Table 3.

\section{mRNA Display}

mRNA display technology utilizes the covalently bonded mRNA-polypeptide complexes formed during in vitro translation, which are linked through puromycin (an analogue of the 3'tyrosyl-tRNA along with mimics of adenosine and tyrosine) via A- site of ribosome. The complexes with desired functions are allowed to bind to the immobilized target protein, reverse transcribed to cDNA and amplified via Polymerase chain reaction (PCR). This enables the reinforcement of DNA template library for next round of screening (Cotten et al. 2012; Newton et al. 2019). The most successful use of mRNA displayed peptide library was described by Litovchick and Szostal (2008), in which they have screened potential AVPs using cyclic peptide-mRNA fusion library targeting Internal ribosomal entry site (IRES) of HCV for inhibition of virions. Another use of this technology was reported for the reverse engineering of peptide vaccines for $\mathrm{HCV}$. High affinity peptides to neutralizing monoclonal antibodies (mAbs) of HCV were selected in this study and used for peptide-based vaccine development (Guo et al. 2015). 


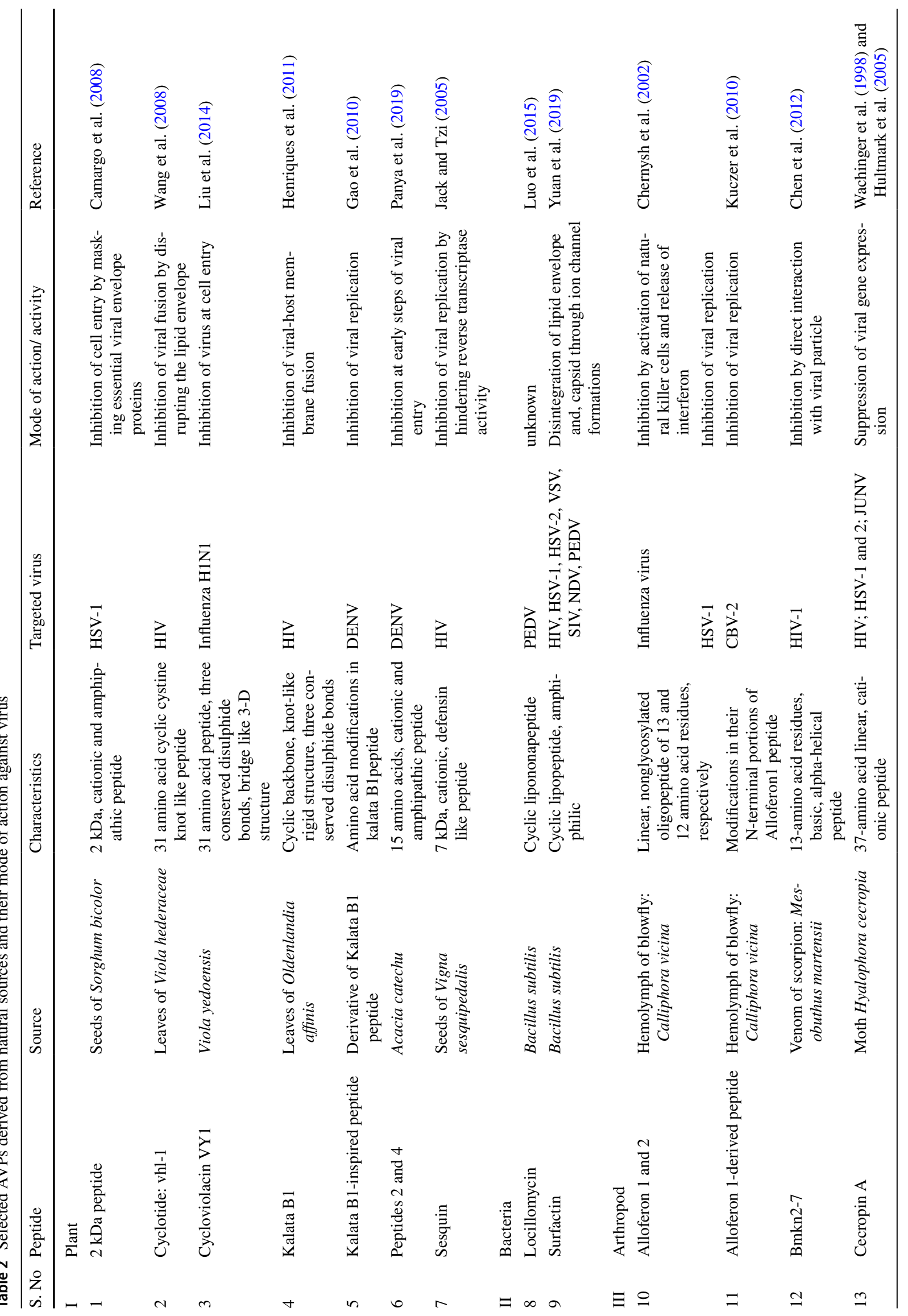




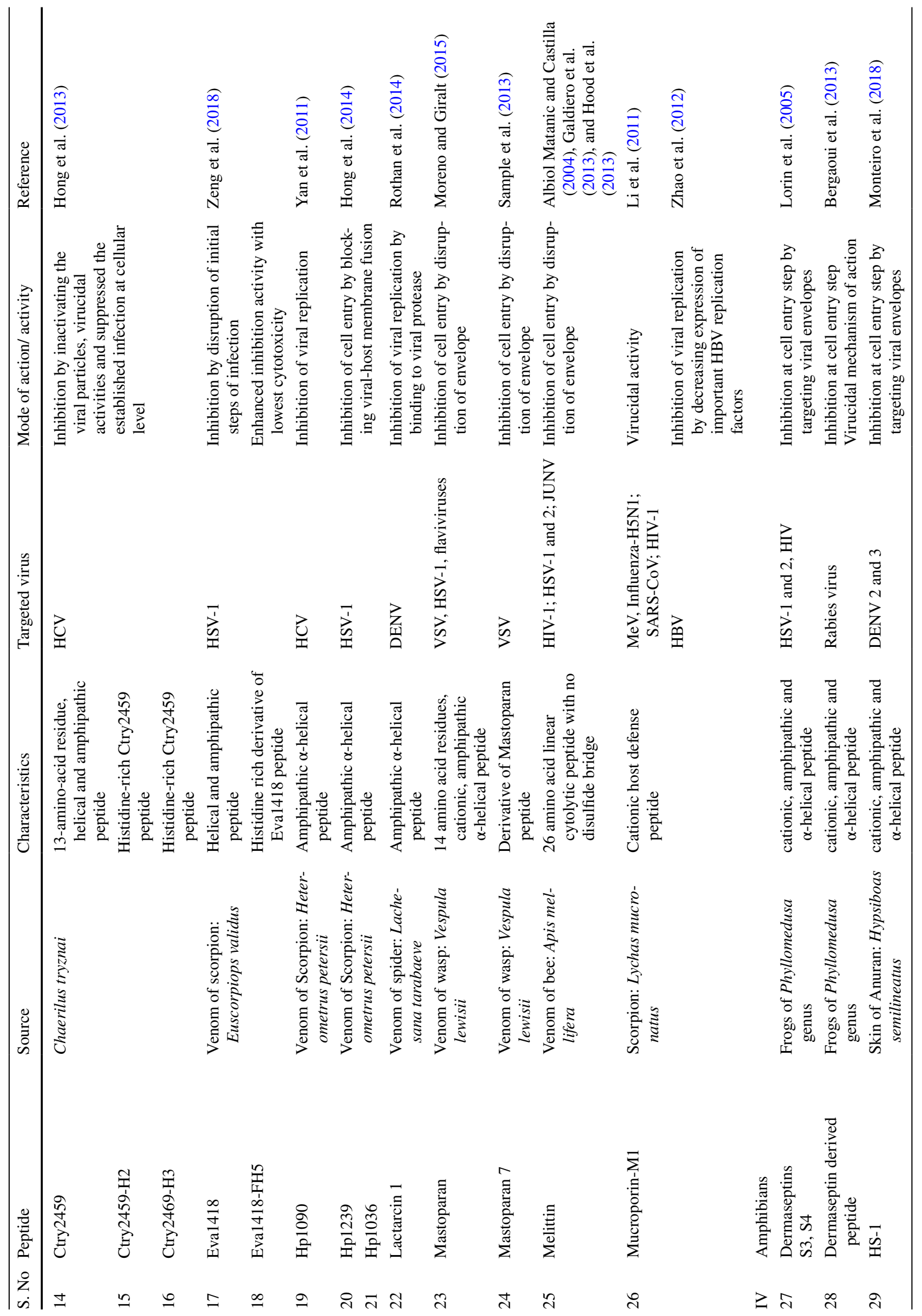




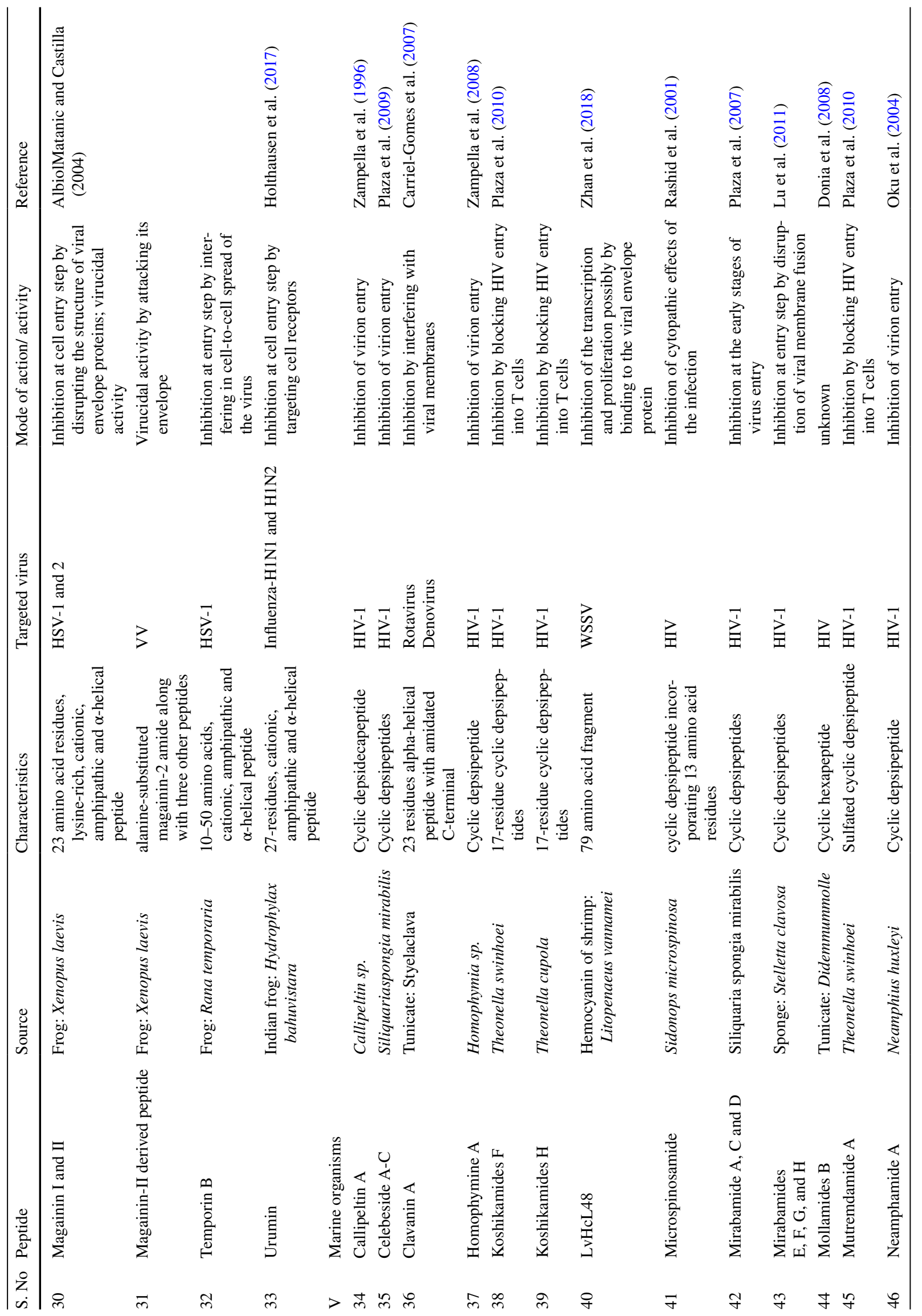




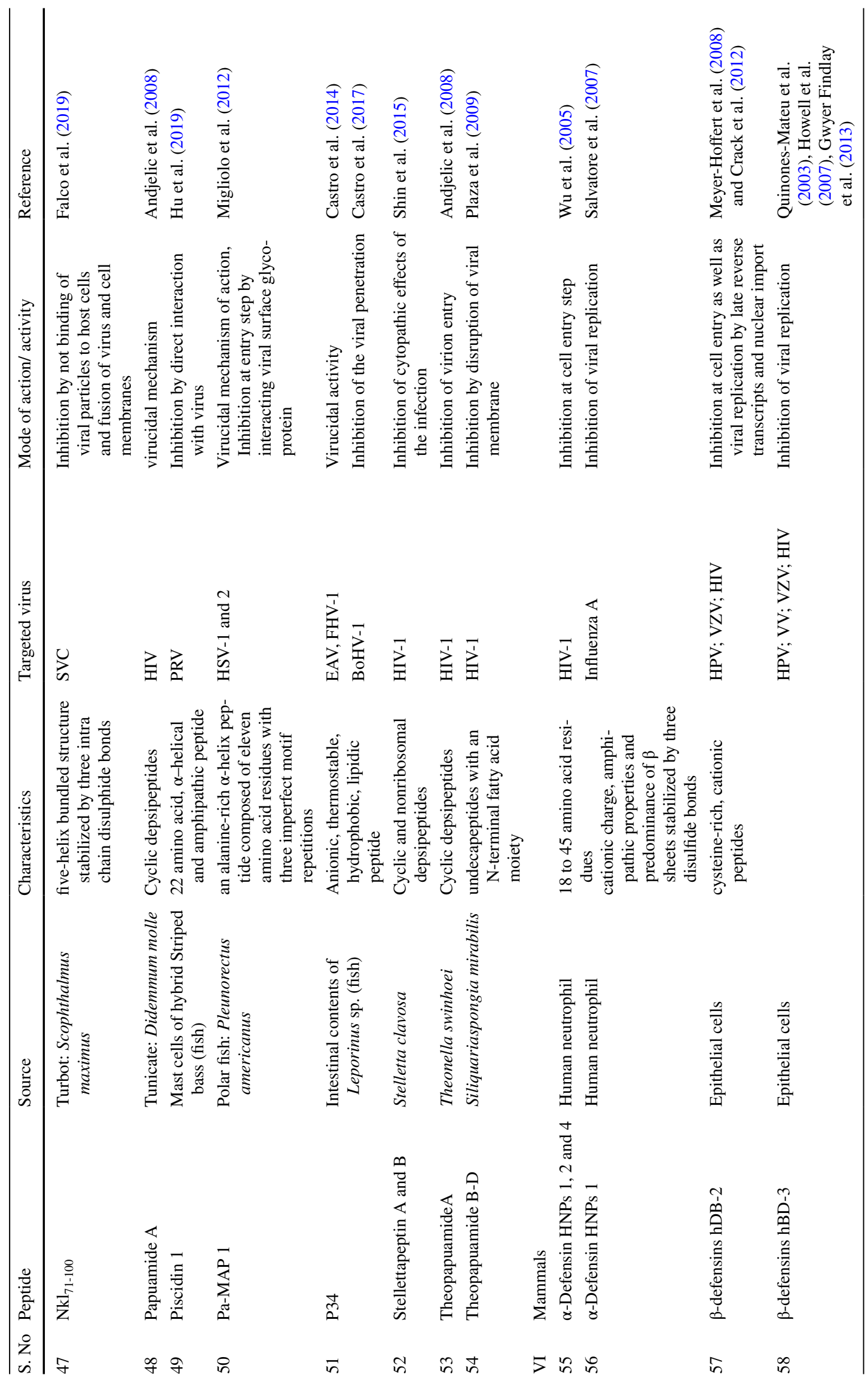




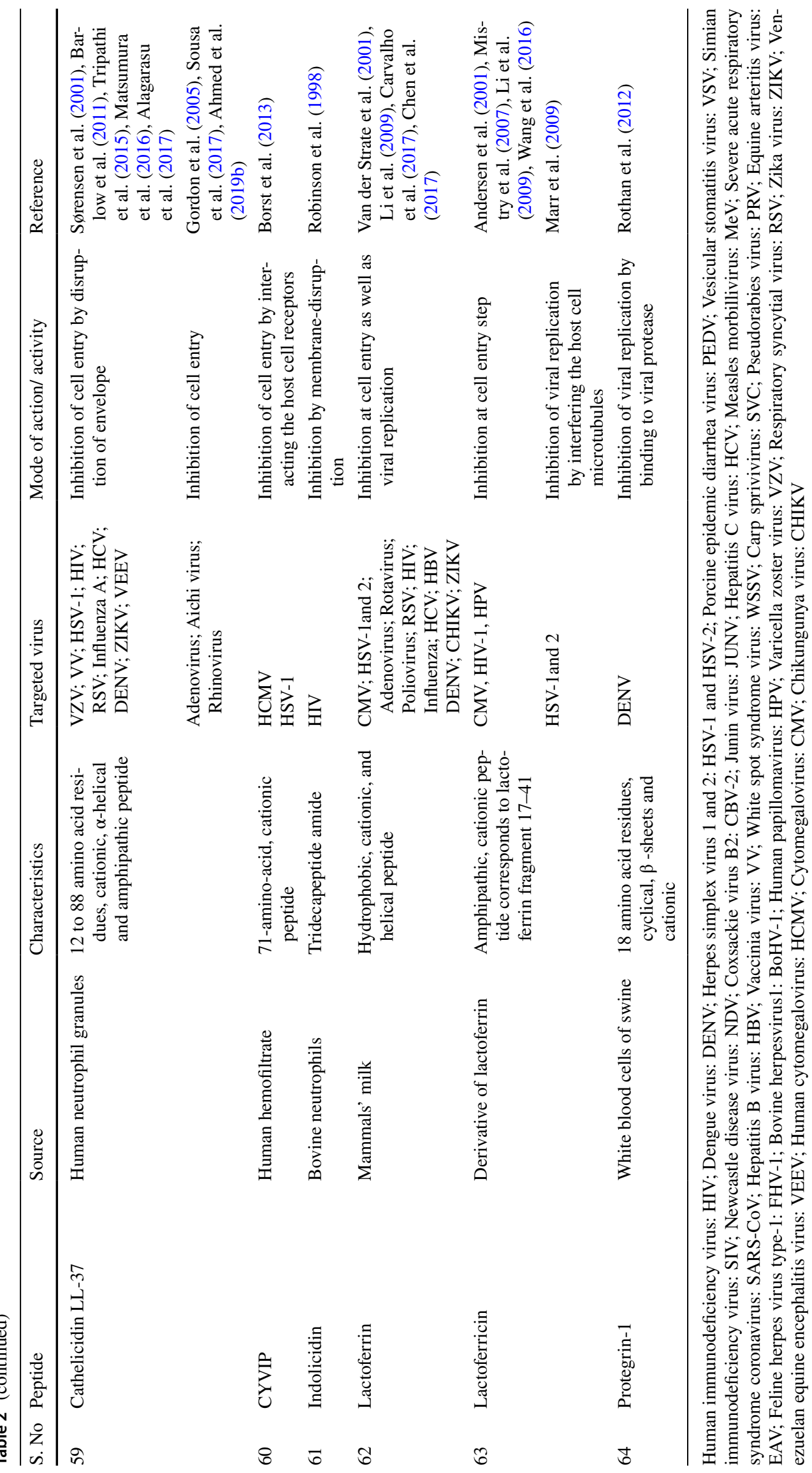




\section{Ribosome Display}

Ribosome display is an entirely in vitro and cell-free system which makes it efficient in comparison to other display systems (Nevola and Giralt 2015). In this system, the coupling of genotype and phenotype is essential for the selection of high affinity peptides from their pool. During in vitro translation, the association between the mRNA, ribosome and the nascent polypeptide leads to a stabilized proteinribosome-mRNA complex. This ternary complex is feasible due to the presence of spacer sequence, without stop codon, inserted into the DNA library coding for proteins/ peptides. The spacer ensures that the peptide folds properly and stays attached to the mRNA and ribosomes. These specific ribosomal complexes that display folded peptides are then allowed to bind to the immobilized target and the non-specific ones are washed off. The mRNA complexes having bound polypeptide chains are recovered and their sequences are obtained (Zahnd et al. 2007). A large library that contains $10^{13}-10^{14}$ clones can be screened as it is not dependent on the living cell system and is free of any bias. This technology has numerous advantages above others as the diversity of library depends on the number of available ribosomes and mRNA in the system rather restricted by the bacterial transformation efficiency (Dreier and Pluckthun 2011). Moreover, such system allows insertion of random mutations at any round of selection since library has not been transformed after any diversification step. The ribosomal display technology has opened a new insight for using peptide inhibitors for early diagnostic as well as therapeutic agent. For instance, the peptide inhibitor against envelope protein $\mathrm{E} 2$ of $\mathrm{HCV}$ was identified using ribosomal display library. After extensive selection of 13 rounds, 12-mer peptides were generated. This peptide named PE2D has not only being verified to bind $\mathrm{E} 2$ protein but also blocks the virus entry inside hepatocyte cells (Chen et al. 2010).

\section{Yeast Display}

The main advantage of the yeast display system over the others is the complete exposure of the peptides/protein for fusion and its compatibility with the fluorescence-activated cell sorting (FACS), which enables the high-throughput screening and characterization of protein/peptide combinatorial libraries (Linciano et al. 2019). Moreover, it also allows the expression of proteins with post translational modifications which has encountered the problem of misfolding in the field of antibody engineering (Mei et al. 2017). Saccharomyces cerevisiae strain based on the Aga1-Aga2 proteins is the most widely used display system. In this system, the protein/peptide is displayed either as $\mathrm{N}$ - or C-terminal fusion to the Aga2 protein of yeast cell, which is linked to the Aga1 via disulphide bonds. Every yeast cell exhibits $\sim 10^{4}-10^{5}$ copies of the Aga2 fusion protein/peptide on its surface though the expression of individuals may vary. The construct of yeast cell also contains two epitope tags at the $\mathrm{N}$ and $\mathrm{C}$ terminus of Aga2 fusion protein, which facilitates the real time quantification of their expression using flow cytometry. Moreover, the tags also enable to estimate and quantify the binding of the target via different labelling approaches (Linciano et al. 2019). Though yeast display system is a valuable platform for screening purpose, however, the library size is restricted due to limited transformation efficiency of yeast. Another major limitation of yeast display is complicated affinity maturation process in comparison to other systems. Besides, these drawbacks, this technology has provided a wide application of high throughput screening in peptide engineering and a platform to study protein-protein/peptide interactions in vivo. In a recent study, this technology was used to screen the hits from a grafted C-peptide library of HIV gp41 against N-peptide trimer of HIVgp41. As a result, four hits suppressed the HIV entry better than others (Tennyson et al. 2018).

\section{Application of Advanced Techniques to Validate Identified Peptides}

Another challenging task in the intervention of antiviral peptides is the corroboration of the binding of selected peptides to the target protein, and their antiviral efficacy. Various techniques have been developed to evaluate the PPIs in vitro/in vivo such as Surface Plasmon Resonance (SPR), Optical based Biolayer interferometry, Fluorescence Resonance Energy Transfer (FRET), Nuclear Magnetic Resonance (NMR), Isothermal Calorimetry (ITC), yeast two hybrid display, microscopic visualization and many more. Some of them can be used for the binding evaluation of the peptides to their target proteins. Since various reviews and reports are available on PPIs detection methods in detail (Nevola and Giralt 2015), this review focuses only on the recent techniques used to determine/ validate the peptide binding efficiency (Table 1).

\section{Surface Plasmon Resonance (SPR)}

SPR is an optical based detection and label-free technique which utilizes the protein in small amount for the real time quantification and evaluation of the binding affinity as well as kinetics between peptide and target protein (Patching 2014). The binding affinity between interacting partners is measured via small variation in the refractive index at sensor surface. This response change is calculated as the change in the angle of resonance of refracted light when flowing analyte binds to the immobilized ligand. The change in the angle of resonance is measured in the form of resonance unit 
Table 3 Characteristics of the AVPs derived from Phage display technology

\begin{tabular}{|c|c|c|c|c|c|}
\hline S. No & Peptide sequence & Library used & Targeted virus & Targeted protein & References \\
\hline 1 & GSHHRHVHSPFV & $\begin{array}{l}\text { 12-mer peptide library: } \\
\text { New England Biolabs } \\
\text { (NEB) }\end{array}$ & $\begin{array}{l}\text { Avian infectious bronchi- } \\
\text { tis virus }\end{array}$ & Purified whole virus & Peng et al. (2006) \\
\hline 2 & HAWDPIPARDPF & \multirow{3}{*}{$\begin{array}{l}\text { 12-mer peptide library } \\
\text { (NEB) }\end{array}$} & \multirow{3}{*}{$\begin{array}{l}\text { Avian influenza A virus- } \\
\text { subtype H5N1 }\end{array}$} & \multirow[t]{3}{*}{ H5N1 viruses } & \multirow[t]{3}{*}{ Wu et al. (2011) } \\
\hline 3 & AAWHLIVALAPN & & & & \\
\hline 4 & ATSHLHVRLPSK & & & & \\
\hline 5 & NDFRSKT & $\begin{array}{l}\text { 7-mer disulfide con- } \\
\text { strained peptide library } \\
\text { (NEB) }\end{array}$ & $\begin{array}{l}\text { Avian influenza virus } \\
\text { H9N2 }\end{array}$ & $\begin{array}{l}\text { AIV sub-type H9N2 } \\
\text { virus particles }\end{array}$ & Rajik et al. (2009) \\
\hline 6 & HSIRYDF & \multirow{2}{*}{$\begin{array}{l}\text { 7-mer peptide Library } \\
\text { (NEB) }\end{array}$} & \multirow{2}{*}{$\begin{array}{l}\text { Bovine ephemeral fever } \\
\text { virus }\end{array}$} & \multirow{2}{*}{$\begin{array}{l}\text { Neutralization site } 1 \text { of } \\
\text { glycoprotein: G1 }\end{array}$} & \multirow[t]{2}{*}{ Hou et al. (2018) } \\
\hline 7 & YSLRSDY & & & & \\
\hline 8 & DRATSSNA & $\begin{array}{l}\text { Octapeptides peptide } \\
\text { library }\end{array}$ & $\begin{array}{l}\text { Classical swine fever } \\
\text { virus }\end{array}$ & Envelope protein: E2 & Yin et al. (2014) \\
\hline 9 & SYQSHYY & \multirow{3}{*}{$\begin{array}{l}\text { 7-mer peptide Library } \\
\text { (NEB) }\end{array}$} & \multirow[t]{3}{*}{ Dengue virus } & \multirow{3}{*}{$\begin{array}{l}\text { Recombinant dengue } \\
\text { envelope protein and its } \\
\text { domain III }\end{array}$} & \multirow{3}{*}{ de la Guardia et al. (2017) } \\
\hline 10 & STSFWIT & & & & \\
\hline 11 & ELLASPW & & & & \\
\hline 12 & CWSFFSNIC & $\begin{array}{l}\text { 7-mer disulfide con- } \\
\text { strained peptide library } \\
\text { (NEB) }\end{array}$ & Hepatitis B virus & Full-length $\mathrm{HBcAg}$ & Ho et al. (2003) \\
\hline 13 & KHMHWHPPALNT & $\begin{array}{l}\text { 12-mer peptide library } \\
\text { (NEB) }\end{array}$ & Hepatitis B virus & PreS1 region of L-protein & Wang et al. (2011) \\
\hline 14 & WTDMFTAWWSTP & $\begin{array}{l}\text { M13-based 12-mer pep- } \\
\text { tide library }\end{array}$ & Hepatitis B virus & Thio-PreS & Deng et al. (2007) \\
\hline 15 & FPWGNTW & $\begin{array}{l}\text { 7-mer disulfide con- } \\
\text { strained peptide library } \\
\text { (NEB) }\end{array}$ & Hepatitis $\mathrm{C}$ virus & $\begin{array}{l}\text { NS5B (del 21-His) } \\
\text { protein }\end{array}$ & Amin et al. (2003) \\
\hline 16 & ATWVCGPCT & $\begin{array}{l}\text { Phage-displayed } \\
\text { nonapeptide library } \\
\text { (PVIII9aa) }\end{array}$ & Hepatitis $\mathrm{C}$ virus & mAb JS-81 against CD81 & Cao et al. (2007) \\
\hline 17 & WPWHNHR & $\begin{array}{l}\text { heptapeptide M13 phage- } \\
\text { display library }\end{array}$ & Hepatitis $\mathrm{C}$ virus & $\begin{array}{l}\text { Truncated envelope } \\
\text { protein E2 }\end{array}$ & Lu et al. (2014) \\
\hline 18 & RINNIPWSEAMM & $\begin{array}{l}\text { libraries of random } \\
\text { 12-mers, 7-mers, and } \\
\text { cyclic 9-mers }\end{array}$ & $\begin{array}{l}\text { Human immunodefi- } \\
\text { ciency virus }\end{array}$ & $\begin{array}{l}\text { Envelope glycoprotein } \\
\text { gp120 }\end{array}$ & Ferrer and Harrison (1999) \\
\hline 19 & VSWPELYKWTWS & $\begin{array}{l}\text { 7-mer disulfide con- } \\
\text { strained peptide library; } \\
\text { 12-mer peptide library } \\
\text { (NEB) }\end{array}$ & $\begin{array}{l}\text { Human immunodefi- } \\
\text { ciency virus }\end{array}$ & mAb VRC01 & Chikaev et al. (2015) \\
\hline 20 & FHNHGKQ & $\begin{array}{l}\text { 7-mer peptide library } \\
\text { (NEB) }\end{array}$ & $\begin{array}{l}\text { Human immunodefi- } \\
\text { ciency virus }\end{array}$ & HIV-1 Integrase & Desjobert et al. (2004) \\
\hline 21 & $\begin{array}{l}\text { GWWYKGRARPVS- } \\
\text { AVA }\end{array}$ & $\begin{array}{l}\text { Pentadecapeptides pep- } \\
\text { tide library }\end{array}$ & Influenza virus A & $\begin{array}{l}\text { Monolayer of the } \\
\text { ganglioside:GM3 }\end{array}$ & Matsubara et al. (2009) \\
\hline 22 & RAVWRHSVATPSHSV & & & & \\
\hline 23 & SENRKVPFYSHS & $\begin{array}{l}\text { 12-mer peptide library } \\
\text { (NEB) }\end{array}$ & $\begin{array}{l}\text { Japanese encephalitis } \\
\text { virus }\end{array}$ & $\begin{array}{l}\text { Domain III of the virus } \\
\text { envelope glycoprotein }\end{array}$ & Zu et al. (2014) \\
\hline 24 & TPDCTRWWCPLT & $\begin{array}{l}\text { 12-mer peptide library } \\
\text { (NEB }\end{array}$ & $\begin{array}{l}\text { Japanese encephalitis } \\
\text { virus }\end{array}$ & E protein & Wei et al. (2019) \\
\hline 25 & RLNNRARIILRA & 12-mer peptide library & Mink enteritis virus & Purified whole virus & Zhang et al. (2012) \\
\hline 26 & LAHKSRLYERHM & (NEB) & & & \\
\hline 27 & CTLTTKLYC & $\begin{array}{l}\text { 7-mer disulfide con- } \\
\text { strained peptide library } \\
\text { (NEB) }\end{array}$ & Newcastle disease virus & Inactivated whole virus & Ramanujam et al. (2002) \\
\hline 28 & EVSHPKVG & \multirow{3}{*}{$\begin{array}{l}\text { Heptapeptide library- } \\
\text { pSKAN8-HyA library }\end{array}$} & \multirow[t]{3}{*}{ Newcastle disease virus } & \multirow[t]{3}{*}{ Inactivated whole virus } & \multirow[t]{3}{*}{ Ozawa et al. (2005) } \\
\hline 29 & SGGSNRSP & & & & \\
\hline 30 & WVTTSNQW & & & & \\
\hline
\end{tabular}


Table 3 (continued)

\begin{tabular}{|c|c|c|c|c|c|}
\hline S. No & Peptide sequence & Library used & Targeted virus & Targeted protein & References \\
\hline 31 & IQTAFNQGA & $\begin{array}{l}\text { 7-mer disulfide con- } \\
\text { strained peptide library } \\
\text { (NEB) }\end{array}$ & $\begin{array}{l}\text { Porcine reproductive and } \\
\text { respiratory syndrome } \\
\text { virus }\end{array}$ & $\begin{array}{l}\text { mAb N3H2 against } \\
\text { nucleocapsid protein }\end{array}$ & Liu et al. (2012) \\
\hline 32 & HRILMRIR & $\begin{array}{l}\text { 12-mer peptide library } \\
\text { (NEB) }\end{array}$ & $\begin{array}{l}\text { Porcine reproductive and } \\
\text { respiratory syndrome } \\
\text { virus }\end{array}$ & ORF1b & An et al. (2005) \\
\hline 33 & CHWMFSPWC & $\begin{array}{l}\text { Random heptapeptide } \\
\text { library } \\
\text { flanked by cysteines }\end{array}$ & Puumala orthohantavirus & Inactivated whole virus & Heiskanen et al. (1997) \\
\hline $\begin{array}{l}34 \\
35\end{array}$ & $\begin{array}{l}\text { TATTEK } \\
\text { VVDGPETKEC }\end{array}$ & $\begin{array}{l}\text { 12-mer peptide library } \\
\text { (NEB) }\end{array}$ & West Nile virus & Non-structural protein 1 & Sun et al. (2011) \\
\hline 36 & P9 peptide & $\begin{array}{l}\text { Peptide library (Spring } \\
\text { Bioscience) }\end{array}$ & West Nile virus & Recombinant E protein & Bai et al. (2007) \\
\hline
\end{tabular}

(RU), where 1RU is equivalent to the $10^{-4} \mathrm{deg} / 10^{-12} \mathrm{gmm}^{-2}$ angle shift. It has become the gold standard in research, typically characterizes the interaction between two molecules in which one is in mobile state and the other is fixed on a gold film. This technique can be used to screen the library of molecules for their binding affinity against a single soluble protein which is immobilized on the sensor surface (Tang et al. 2010). Thus, SPR has emerged as a powerful technique in therapeutic intervention. It can also be adapted to study the interactions involving complicated proteins in situ, such as, membrane-bound proteins, ion channels and other growth, immune and cellular receptors, which are considered as potential targets for drug discovery (Patching 2014). Bai et al. (2007) have investigated the affinity interaction of screened peptides to the Envelope protein of West Nile virus (WNV) using SPR, in which they found peptide P9 to have the highest affinity to the target. Besides this, in another study, the binding of Helix-A peptide to the neuronal microtubules (MTs): $\beta$-tubulin was determined by SPR. Helix-A peptide prevents the binding of the gp120 protein of HIV to the $\beta$-tubulin, a neuronal MT and possesses neuroprotective activity (Avdoshina et al. 2019). Moreover, the SPR has been used as a ligand screening strategy for Influenza virus and HSV-1, in which the technique enables the continuous screening of inhibitors that inhibit the viral entry. The major advantage of this technique is the use of minimal amount of immobilized viral surface proteins or receptors as compared to other techniques (Kumar 2017).

\section{Biolayer Interferometry}

Another optical based and label-free technique is the Biolayer interferometry (BLI) which validates the interaction between two molecules by quantifying the change in an interference pattern. The target molecule is immobilized on the tip of fiber optic biosensor that moves toward the wells containing the binding partner present in solution. The association and dissociation of the binding partner with the immobilized molecule is monitored by BLI, leading to the generation of optical thickness at the tip of biosensor that produces an optical interference pattern. This pattern can be quantified and used to determine real time kinetic rates of binding and dissociation (Shah and Duncan 2014). Thus, it has become a valuable tool for monitoring interactions between small molecules in the field of drug discovery. This technique is advantageous over others as nonspecific and non ideal interactions can be differentiated in initial steps by examining their binding response and moreover, it has low false positive rate. Besides, the varied flow rate, available unbound molecules and the refractive index of adjacent medium do not affect the obtained interference pattern, which is the unique property of this technique (Wartchow et al. 2011). In this context $\mathrm{Zu}$ et al. (2014) have analysed the real time binding affinity of chemically synthesized screened peptides to the Domain III of JEV envelope protein and reported peptide $\mathrm{P} 3$ possessed the highest affinity.

\section{Fluorescence Resonance Energy Transfer (FRET)}

FRET is a sensitive method to investigate the interaction of proteins with large diverse set of peptides/proteins libraries for high throughput screening efficiently. This technique is reliable on the distance-dependent transfer of energy between dye-labelled molecules, where the excited donor fluorophore transfers its energy to an acceptor chromophore (Rogers et al. 2012). This energy transfer determines the ratio metric signal generated by the reduction in fluorescence of donor molecule and the increment in fluorescence of acceptor molecule. The technique of FRET can be used as both screening as well as validation method. In view of this, various FRET based studies have been reported for the identification of potent inhibitors against several viral proteases such as SARS coronavirus 3CLpro protease, DENV NS2BNS3 protease, WNV Serine Protease, HCV NS3/4A protease 
and HIV protease. Similarly, a FRET based proteolytic assay was used to screen the compounds against CHIKV capsid protein (Aggarwal et al. 2015).

\section{Challenges to the Peptide as Therapeutic Use}

Several limitations that obstruct the way of peptide to be a successful therapeutic drug, are its instability, short halflife, lower potency, inability to cross membrane barriers and poor bioavailability due to protease degradation (Ali et al. 2013). The main challenge is to overcome these limitations and to achieve the desired efficacy for the required time span. Various modifications have been employed to enhance the stability and physiochemical properties of the peptides (Gentilucci et al. 2010). For instance, the conjugation of peptide to polymers such as polyethylene glycol (PEG) has enhanced the stability of peptides by increasing their molecular weight (Chew et al. 2017). Likewise, the bioavailability was improved by balancing the aqueous solubility via replacement of redundant hydrophobic amino acids to charged/polar residues (Mant et al. 2009; Wu et al. 2010). Moreover, there are two computational softwares based on support-vector machine (SVM) to predict the solubility of the peptides, thus assisting in the designing and optimising the peptide bioavailability (Lee et al. 2019). In addition to the strategies involved in the improvement of peptide properties, the delivery of peptides has also been improved by linking of peptides to the cell penetrating peptides (CPPs) to enhance their cell permeability (Chew et al. 2017). CPPs are general peptides ( $<30$ amino acids) derived from natu$\mathrm{ral} /$ unnatural sources or chimeric sequences, considered as promising carrier for successful delivery of therapeutic molecules varying from small chemical molecules, liposomes, proteins, peptides and nucleic acids for in vitro as well as in vivo applications (Heitz et al. 2009). Alternatively, peptides can be encapsulated in nanoparticles for efficient delivery, or administered through primary parental or transdermal routes with variations such as prefilled syringes, auto injectors and biodegradable micro needles (Lee et al. 2019). These modifications help to address the challenges of poor ADME properties of non-modified peptides (Lau and Dunn 2018).

\section{Conclusion}

In summary, the discovery of the peptide-based therapies have made a significant impact in the research. Many peptide therapies are available in the clinical and pre-clinical trials which are expected to yield positive results. The various approaches including computational, natural and biological sources provide a wide repository for identification of peptides involved in viral therapeutics. These promising therapeutics/inhibitors are advantageous because of their high specificity, selectivity against target and can be easily developed without the prior structural knowledge of target (except docking). Novel technologies like SPR, BLI and FRET validate the binding of identified peptides to their target which further aid in the selection of high affinity potential AVPs. However, there is a dearth of knowledge in the field of identification and characterization of antiviral therapeutics; further advancement and commercialization of peptide-based therapeutics is warranted.

Acknowledgements The authors acknowledge Jaypee Institute of Information Technology (JIIT), Noida for providing infrastructure facilities.

Author Contributions GA reviewed the literature and wrote the manuscript. RG conceived the idea and finalized the manuscript.

Funding GA is funded by the Department of Science and Technology, Government of India: DST-INSPIRE (IF 150104).

\section{Compliance with Ethical Standards}

Conflict of interest The authors declare that they have no conflict of interest in the publication.

Ethical Approval This is a review article which does not contain any type of studies related to human or animal participants.

\section{References}

Aggarwal M, Sharma R, Kumar P, Parida M, Tomar S (2015) Kinetic characterization of trans-proteolytic activity of Chikungunya virus capsid protease and development of a FRET-based HTS assay. Sci Rep 5:14753. https://doi.org/10.1038/srep14753

Ahmed A, Siman-Tov G, Hall G, Bhalla N, Narayanan A (2019a) Human antimicrobial peptides as therapeutics for viral infections. Viruses 11:704. https://doi.org/10.3390/v11080704

Ahmed A, Siman-Tov G, Keck F, Kortchak S, Bakovic A, Risner K, Lu TK, Bhalla N, de la Fuente-Nunez C, Narayanan A (2019b) Human cathelicidin peptide LL-37 as a therapeutic antiviral targeting Venezuelan equine encephalitis virus infections. Antiviral Res 164:61-69. https://doi.org/10.1016/j.antiviral.2019.02.002

Alagarasu K, Patil PS, Shil P, Seervi M, Kakade MB, Tillu H, Salunke A (2017) In-vitro effect of human cathelicidin antimicrobial peptide LL-37 on dengue virus type 2. Peptides 92:23-30. https:// doi.org/10.1016/j.peptides.2017.04.002

Albiol Matanic VC, Castilla V (2004) Antiviral activity of antimicrobial cationic peptides against Junin virus and herpes simplex virus. Int J Antimicrob Agents 23:382-389. https://doi. org/10.1016/j.ijantimicag.2003.07.022

Ali R, Rani R, Kumar S (2013) New peptide based therapeutic approaches. In: Ashraf GMd, Sheikh IA (eds) Advances in protein chemistry. OMICS Group eBooks, Jeddah

Amin A, Zaccardi J, Mullen S, Olland S, Orlowski M, Feld B, Labonte P, Mak P (2003) Identification of constrained peptides that bind to and preferentially inhibit the activity of the hepatitis $\mathrm{C}$ viral 
RNA-dependent RNA polymerase. Virology 313:158-169. https ://doi.org/10.1016/S0042-6822(03)00313-1

An TQ, Zhou YJ, Qiu HJ, Tong GZ, Wang YF, Liu JX, Yang JY (2005) Identification of a Novel B cell epitope on the nucleocapsid protein of porcine reproductive and respiratory syndrome virus by phage display. Virus Genes 31:81-87. https://doi.org/10.1007/ s11262-005-2203-1

Andersen JH, Osbakk SA, Vorland LH et al (2001) Lactoferrin and cyclic lactoferricin inhibit the entry of human cytomegalovirus into human fibroblasts. Antiviral Res 51:141-149. https://doi. org/10.1016/s0166-3542(01)00146-2

Andjelic CD, Planelles V, Barrows LR (2008) Characterizing the antiHIV activity of Papuamide A. Mar Drugs 6:528-549. https://doi. org/10.3390/md20080027

Avdoshina V, Taraballi F, Tasciotti E, Uren A, Mocchetti I (2019) Helix-A peptide prevents gp120-mediated neuronal loss. Mol Brain 12:61. https://doi.org/10.1186/s13041-019-0482-z

Badani H, Garry RF, Wimley WC (2014) Peptide entry inhibitors of enveloped viruses: the importance of interfacial hydrophobicity. Biochim Biophys Acta Biomembr 1838:2180-2197. https://doi. org/10.1016/j.bbamem.2014.04.015

Bai F, Town T, Pradhan D, Cox J, Ledizet M, Anderson JF, Flavell RA, Krueger JK, Koski RA, Fikrig E (2007) Antiviral peptides targeting the West Nile virus envelope protein. J Virol 81:2047-2055. https://doi.org/10.1128/JVI.01840-06

Barlow PG, Svoboda P, Mackellar A, Nash AA, York IA, Pohl J, Davidson DJ, Donis RO (2011) Antiviral activity and increased host defense against influenza infection elicited by the human cathelicidin LL-37. PLoS ONE 6:1-9. https://doi.org/10.1371/ journal.pone. 0025333

Bergaoui I, Zairi A, Tangy F, Aouni M, Selmi B, Hani K (2013) In vitro antiviral activity of dermaseptin $\mathrm{S} 4$ and derivatives from amphibian skin against herpes simplex virus type 2. J Med Virol 85:272281. https://doi.org/10.1002/jmv. 23450

Bogomolov P, Alexandrov A, Voronkova N, Macievich M, Kokina K, Petrachenkova M, Lehr T, Lempp FA, Wedemeyer H, Haag M, Schwab M (2016) Treatment of chronic hepatitis D with the entry inhibitor myrcludex B: First results of a phase Ib/IIa study. J Hepatol 65:490-498. https://doi.org/10.1016/j.jhep.2016.04.016

Borst EM, Ständker L, Wagner K et al (2013) A peptide inhibitor of cytomegalovirus infection from human hemofiltrate. Antimicrob Agents Chemother 57:4751-4760. https://doi.org/10.1128/ aac.00854-13

Bulet P, Stöcklin R, Menin L (2004) Anti-microbial peptides: from invertebrates to vertebrates. Immunol Rev 198:169-184. https:// doi.org/10.1111/j.0105-2896.2004.0124.x

Camargo Filho I, Cortez DAG, Ueda-Nakamura T, Nakamura CV, Dias Filho BP (2008) Antiviral activity and mode of action of a peptide isolated from Sorghum bicolor. Phytomedicine 15:202-208. https://doi.org/10.1016/j.phymed.2007.07.059

Cao J, Liao XL, Wu SM, Zhao P, Zhao LJ, Wu WB, Qi ZT (2007) Selection of a phage-displayed peptide recognized by monoclonal antibody directed blocking the site of hepatitis C virus E2 for human CD81. J Microbiol Methods 68:601-604. https://doi. org/10.1016/j.mimet.2006.11.009

Carriel-Gomes MC, Kratz JM, Barracco MA, Bachére E, Barardi CR, Simões CM (2007) In vitro antiviral activity of antimicrobial peptides against herpes simplex virus 1, adenovirus, and rotavirus. Mem Inst Oswaldo Cruz 102:469-472. https://doi. org/10.1590/s0074-02762007005000028

Carvalho CAM, Casseb SMM, Gonçalves RB, Silva EV, Gomes AM, Vasconcelos PF (2017) Bovine lactoferrin activity against Chikungunya and Zika viruses. J Gen Virol 98:1749-1754. https:// doi.org/10.1099/jgv.0.000849

Castro CC, Sant'anna V, Vargas GD, Lima MD, Fischer G, Brandelli A, Motta AD, Hübner SD (2014) Antiviral activity of a Bacillus sp: P34 peptide against pathogenic viruses of domestic animals. Braz J Microbiol 45:1089-1094. https://doi. org/10.1590/s1517-83822014000300043

Castro CC, Silva DS, Costa GA, Fischer G, Vargas GD, Brandelli A, Lima MD, Motta AD, Hubner SD (2017) Activity of the antimicrobial peptide $\mathrm{P} 34$ against bovine alpha herpes virus type 1. Ciência Rural 47:e20160668. https://doi.org/10.1590/0103$8478 \mathrm{cr} 20160668$

Chen F, Zhao Y, Liu M, Li D, Wu H, Chen H, Zhu Y, Luo F, Zhong J, Zhou Y, Qi Z (2010) Functional selection of hepatitis C virus envelope E2-binding Peptide ligands by using ribosome display. Antimicrob Agents Chemother 54:3355-3364. https:// doi.org/10.1128/aac.01357-09

Chen Y, Cao L, Zhong M, Zhang Y, Han C, Li Q, Yang J, Zhou D, Shi W, He B, Liu F (2012) Anti-HIV-1 activity of a new scorpion venom peptide derivative Kn2-7. PLoS ONE 7:1-9. https ://doi.org/10.1371/journal.pone.0034947

Chen JM, Fan YC, Lin JW, Chen YY, Hsu WL, Chiou SS (2017) Bovine lactoferrin inhibits dengue virus infectivity by interacting with heparan sulfate, low-density lipoprotein receptor and DC-SIGN. Int J Mol Sci 18:1-13. https://doi.org/10.3390/ ijms 18091957

Chernysh S, Kim SI, Bekker G, Pleskach VA, Filatova NA, Anikin VB, Platonov VG, Bulet P (2002) Antiviral and antitumor peptides from insects. Proc Natl Acad Sci 99:12628-12632. https ://doi.org/10.1073/pnas.192301899

Chew MF, Poh KS, Poh CL (2017) Peptides as therapeutic agents for dengue virus. Int J Med Sci 14:1342-1359. https://doi. org/10.7150/ijms.21875

Chikaev AN, Bakulina AY, Burdick RC, Karpenko LI, Pathak VK, Ilyichev AA (2015) Selection of Peptide Mimics of HIV-1 Epitope Recognized by Neutralizing Antibody VRC01. PLoS ONE 10:e0120847. https://doi.org/10.1371/journal.pone.01208 47

Cotten SW, Zou J, Wang R, Huang BC, Liu R (2012) mRNA display-based selections using synthetic peptide and natural protein libraries. Methods Mol Biol 805:287-297. https://doi. org/10.1007/978-1-61779-379-0_16

Crack LR, Jones L, Malavige GN, Patel V, Ogg GS (2012) Human antimicrobial peptides LL-37 and human $\beta$-defensin- 2 reduce viral replication in keratinocytes infected with varicella zoster virus. Clin Exp Dermatol 37:534-543. https://doi.org/10.111 $1 / \mathrm{j} .1365-2230.2012 .04305 . \mathrm{x}$

de la Guardia C, Quijada M, Lleonart R (2017) Phage-displayed peptides selected to bind envelope glycoprotein show antiviral activity against dengue virus serotype 2. Adv Virol 2017:1827341. https://doi.org/10.1155/2017/1827341

Deng Q, Zhai JW, Michel ML, Zhang J, Qin J, Kong YY, Zhang XX, Budkowska A, Tiollais P, Wang Y, Xie YH (2007) Identification and characterization of peptides that interact with hepatitis B virus via the putative receptor binding site. J Virol 81:42444254. https://doi.org/10.1128/jvi.01270-06

Desjobert C, de Soultrait VR, Faure A, Parissi V, Litvak S, TarragoLitvak L, Fournier M (2004) Identification by phage display selection of a short peptide able to inhibit only the strand transfer reaction catalyzed by human immunodeficiency virus type 1 integrase. Biochemistry 43:13097-13105. https://doi.org/10.1021/ bi049385e

Divyashree M, Mani MK, Reddy D, Kumavath R, Ghosh P, Azevedo V, Barh D (2020) Clinical applications of antimicrobial peptides (AMPs): where do we stand now? Protein Pept Lett 27:120-134. https://doi.org/10.2174/0929866526666190925152957

Donia MS, Wang B, Dunbar DC, Desai PV, Patny A, Avery M, Hamann MT (2008) Mollamides B and C, Cyclic Hexapeptides from the Indonesian Tunicate Didemnum molle. J Nat Prod 71:941-945. https://doi.org/10.1021/np700718p 
Dreier B, Pluckthun A (2011) Ribosome display: a technology for selecting and evolving proteins from large libraries. Methods Mol Biol 687:283-306. https://doi.org/10.1007/978-1-60761 -944-4_21

Falco A, Medina-Gali R, Poveda J, Bello-Perez M, Novoa B, Encinar JA (2019) Antiviral activity of a Turbot (Scophthalmus maximus) NK-lysin peptide by inhibition of low-pH virus-induced membrane fusion. Mar Drugs 17:87. https://doi.org/10.3390/ md 17020087

Ferrer M, Harrison SC (1999) Peptide ligands to human immunodeficiency virus type $1 \mathrm{gp} 120$ identified from phage display libraries. J Virol 73:5795-5802

Fukunaga K, Taki M (2012) Practical tips for construction of custom peptide libraries and affinity selection by using commercially available phage display cloning systems. J Nucleic Acids 2012:295719. https://doi.org/10.1155/2012/295719

Galdiero S, Falanga A, Tarallo R, Russo L, Galdiero E, Cantisani M, Morelli G, Galdiero M (2013) Peptide inhibitors against herpes simplex virus infections. J Pept Sci 19:148-158. https://doi. org/10.1002/psc.2489

Gao Y, Cui T, Lam Y (2010) Synthesis and disulfide bond connectivity-activity studies of a kalata B1-inspired cyclopeptide against dengue NS2B-NS3 protease. Bioorganic Med Chem 18:13311336. https://doi.org/10.1016/j.bmc.2009.12.026

Gentilucci L, De Marco R, Cerisoli L (2010) Chemical modifications designed to improve peptide stability: incorporation of non-natural amino acids, pseudo-peptide bonds, and cyclization. Curr Pharm Des 16:3185-3203. https://doi.org/10.2174/1381612107 93292555

Gordon YJ, Huang LC, Romanowski EG et al (2005) Human cathelicidin (LL-37), a multifunctional peptide, is expressed by ocular surface epithelia and has potent antibacterial and antiviral activity. Curr Eye Res 30:385-394. https://doi.org/10.1080/02713 680590934111

Guo N, Duan H, Kachko A, Krause BW, Major ME, Krause PR (2015) Reverse engineering of vaccine antigens using high throughput sequencing enhanced mRNA display. EBioMedicine 2:859-867. https://doi.org/10.1016/j.ebiom.2015.06.021

Gwyer Findlay E, Currie SM, Davidson DJ (2013) Cationic host defence peptides: potential as antiviral therapeutics. BioDrugs 27:479-493. https://doi.org/10.1007/s40259-013-0039-0

Heiskanen T, Lundkvist A, Vaheri A, Lankinen H (1997) Phage-displayed peptide targeting on the Puumala hantavirus neutralization site. J Virol 71(5):3879-3885

Heitz F, Morris MC, Divita G (2009) Twenty years of cell-penetrating peptides: from molecular mechanisms to therapeutics. Br J Pharmacol 157:195-206. https://doi.org/10.111 1/j.1476-5381.2009.00057.x

Henriques ST, Huang YH, Rosengren KJ, Franquelim HG, Carvalho FA, Johnson A, Sonza S, Tachedjian G, Castanho MA, Daly NL, Craik DJ (2011) Decoding the membrane activity of the cyclotide kalata B1: the importance of phosphatidylethanolamine phospholipids and lipid organization on hemolytic and anti-HIV activities. J Biol Chem 286:1-24. https://doi.org/10.1074/jbc. m111.253393

Ho KL, Yusoff K, Seow HF, Tan WS (2003) Selection of high affinity ligands to hepatitis B core antigen from a phage-displayed cyclic peptide library. J Med Virol 69:27-32. https://doi.org/10.1002/ jmv. 10266

Holthausen DJ, Lee SH, Kumar VT, Bouvier NM, Krammer F, Ellebedy AH, Wrammert J, Lowen AC, George S, Pillai MR, Jacob J (2017) An amphibian host defense peptide is virucidal for human $\mathrm{H} 1$ hemagglutinin bearing influenza viruses. Immunity 46:587-595. https://doi.org/10.1016/j.immuni.2017.03.018

Hong W, Zhang R, Di Z, He Y, Zhao Z, Hu J, Wu Y, Li W, Cao Z (2013) Design of histidine-rich peptides with enhanced bioavailability and inhibitory activity against hepatitis $\mathrm{C}$ virus. Biomaterials 34:3511-3522. https://doi.org/10.1016/j.biomateria 1s.2013.01.075

Hong W, Li T, Song Y, Zhang R, Zeng Z, Han S, Zhang X, Wu Y, Li W, Cao Z (2014) Inhibitory activity and mechanism of two scorpion venom peptides against herpes simplex virus type 1 . Antiviral Res 102:1-10. https://doi.org/10.1016/j.antiviral.2013.11.013

Hood JL, Jallouk AP, Campbell N, Ratner L, Wickline SA (2013) Cytolytic nanoparticles attenuate HIV-1 infectivity. Antivir Ther 18:95-103. https://doi.org/10.3851/imp2346

Hou P, Zhao G, He C, Wang H, He H (2018) Biopanning of polypeptides binding to bovine ephemeral fever virus $\mathrm{G} 1$ protein from phage display peptide library. BMC Vet Res 14:3. https://doi. org/10.1186/s12917-017-1315-x

Howell MD, Streib JE, Leung DYM (2007) Antiviral activity of human beta-defensin 3 against vaccinia virus. J Allergy Clin Immunol 119:1022-1025. https://doi.org/10.1016/j.jaci.2007.01.044

Hu H, Guo N, Chen S, Guo X, Liu X, Ye S, Chai Q, Wang Y, Liu B, He Q (2019) Antiviral activity of Piscidin 1 against pseudorabies virus both in vitro and in vivo. Virol J 16:95. https://doi. org/10.1186/s12985-019-1199-4

Hultmark D, Steiner H, Rasmuson T, Boman HG (2005) Insect immunity. Purification and properties of three inducible bactericidal proteins from hemolymph of immunized pupae of Hyalophora cecropia. Eur J Biochem 106:7-16. https://doi. org/10.1111/j.1432-1033.1980.tb05991.x

Ireland DC, Wang CKL, Wilson JA, Gustafson KR, Craik DJ (2008) Cyclotides as natural anti-HIV agents. Biopolym - Pept Sci Sect 90:51-60. https://doi.org/10.1002/bip.20886

Jack HW, Tzi BN (2005) Sesquin, a potent defensin-like antimicrobial peptide from ground beans with inhibitory activities toward tumor cells and HIV-1 reverse transcriptase. Peptides 26:1120 1126. https://doi.org/10.1016/j.peptides.2005.01.003

Jenssen H (2009) Therapeutic approaches using host defence peptides to tackle herpes virus infections. Viruses 1:939-964. https://doi. org/10.3390/v1030939

Kuczer M, Dziubasik K, Midak-Siewirska A, Zahorska R, Luczak M, Konopinska D (2010) Studies of insect peptides alloferon, AnyGS and their analogues. Synthesis and antiherpes activity. J Pept Sci 16:186-189. https://doi.org/10.1002/psc.1219

Kumar PKR (2017) Systematic screening of viral entry inhibitors using surface plasmon resonance. Rev Med Virol 27:e1952. https://doi. org/10.1002/rmv.1952

Lau JL, Dunn MK (2018) Therapeutic peptides: Historical perspectives, current development trends, and future directions. Bioorg Med Chem 26:2700-2707. https://doi.org/10.1016/j.bmc.2017.06.052

Lee AC, Harris JL, Khanna KK, Hong JH (2019) A comprehensive review on current advances in peptide drug development and design. Int J Mol Sci 20:2383. https://doi.org/10.3390/ijms2 0102383

Li S, Zhou H, Huang G, Liu N (2009) Inhibition of HBV infection by bovine lactoferrin and iron, zinc-saturated lactoferrin. Med Microbiol Immunol 198:19-25. https://doi.org/10.1007/s0043 0-008-0100-7

Li Q, Zhao Z, Zhou D, Chen Y, Hong W, Cao L, Yang J, Zhang Y, Shi W, Cao Z, Wu Y (2011) Virucidal activity of a scorpion venom peptide variant mucroporin-M1 against measles, SARS $\mathrm{CoV}$ and influenza H5N1 viruses. Peptides 32:1518-1525. https ://doi.org/10.1016/j.peptides.2011.05.015

Linciano S, Pluda S, Bacchin A, Angelini A (2019) Molecular evolution of peptides by yeast surface display technology. Med Chem Comm 10:1569-1580. https://doi.org/10.1039/c9md00252a

Litovchick A, Szostak JW (2008) Selection of cyclic peptide aptamers to HCV IRES RNA using mRNA display. Proc Natl Acad Sci USA 105:15293-15298. https://doi.org/10.1073/pnas.08058 37105 
Liu K, Feng X, Ma Z, Luo C, Zhou B, Cao R, Huang L, Miao D, Pang R, He D, Lian X, Chen P (2012) Antiviral activity of phage display selected peptides against Porcine reproductive and respiratory syndrome virus in vitro. Virology 432:73-80. https://doi. org/10.1016/j.virol.2012.05.010

Liu MZ, Yang Y, Zhang SX, Tang L, Wang HM, Chen CJ, Shen ZF, Cheng KD, Kong JQ, Wang W (2014) A cyclotide against influenza A H1N1 virus from Viola yedoensis. Yao xue xue bao. Acta Pharm Sin 49:905-912

Lorin C, Saidi H, Belaid A et al (2005) The antimicrobial peptide Dermaseptin S4 inhibits HIV-1 infectivity in vitro. Virology 334:264-275. https://doi.org/10.1016/j.virol.2005.02.002

Lu Z, Van Wagoner RM, Harper MK, Baker HL, Hooper JNA, Bewley CA, Ireland CM (2011) Mirabamides E-H, HIV-Inhibitory Depsipeptides from the Sponge Stelletta clavosa. J Nat 74:185-193. https://doi.org/10.1021/np100613p

Lu X, Yao M, Zhang JM, Yang J, Lei YF, Huang XJ, Jia ZS, Ma L, Lan HY, Xu ZK, Yin W (2014) Identification of peptides that bind hepatitis $\mathrm{C}$ virus envelope protein $\mathrm{E} 2$ and inhibit viral cellular entry from a phage-display peptide library. Int J Mol Med 33:1312-1318. https://doi.org/10.3892/ijmm.2014.1670

Luo C, Liu X, Zhou X, Guo J, Truong J, Wang X, Zhou H, Li X, Chen Z (2015) Unusual biosynthesis and structure of locillomycins from Bacillus subtilis 916. Appl Environ Microbiol 81:66016609. https://doi.org/10.1128/aem.01639-15

Mant CT, Kovacs JM, Kim HM, Pollock DD, Hodges RS (2009) Intrinsic amino acid side-chain hydrophilicity/hydrophobicity coefficients determined by reversed-phase high-performance liquid chromatography of model peptides: comparison with other hydrophilicity/hydrophobicity scales. Biopolymers 92:573-595. https://doi.org/10.1002/bip.21316

Marr AK, Jenssen H, Moniri MR, Hancock RE, Panté N (2009) Bovine lactoferrin and lactoferricin interfere with intracellular trafficking of Herpes simplex virus-1. Biochimie 91:160-164. https://doi. org/10.1016/j.biochi.2008.05.016

Mascini M, Dikici E, Robles Mañueco M, Perez-Erviti JA, Deo SK, Compagnone D, Wang J, Pingarrón JM, Daunert S (2019) Computationally designed peptides for Zika virus detection: an incremental construction approach. Biomolecules 9:498. https://doi. org/10.3390/biom 9090498

Matsubara T (2012) Potential of peptides as inhibitors and mimotopes: selection of carbohydrate-mimetic peptides from phage display libraries. J Nucleic Acids. https://doi.org/10.1155/2012/740982

Matsubara T, Sumi M, Kubota H, Taki T, Okahata Y, Sato T (2009) Inhibition of influenza virus infections by sialylgalactose-binding peptides selected from a phage library. J Med Chem 52:42474256. https://doi.org/10.1021/jm801570y

Matsumura T, Sugiyama N, Murayama A, Yamada N, Shiina M, Asabe S, Wakita T, Imawari M, Kato T (2016) Antimicrobial peptide LL-37 attenuates infection of hepatitis C virus. Hepatol Res 46:924-932. https://doi.org/10.1111/hepr.12627

Mei M, Zhou Y, Peng W, Yu C, Ma L, Zhang G, Yi L (2017) Application of modified yeast surface display technologies for nonAntibody protein engineering. Microbiol Res 196:118-128. https ://doi.org/10.1016/j.micres.2016.12.002

Meyer-Hoffert U, Schwarz T, Schroder J-M, Gläser R (2008) Expression of human beta-defensin-2 and -3 in verrucae vulgares and condylomata acuminata. J Eur Acad Dermatol Venereol 22:1050-1054. https://doi.org/10.1111/j.1468-3083.2008.02675 . $\mathrm{x}$

Migliolo L, Silva ON, Silva PA, Costa MP, Costa CR, Nolasco DO, Barbosa JA, Silva MR, Bemquerer MP, Lima LM, Romanos MT (2012) Structural and functional characterization of a multifunctional alanine-rich peptide analogue from pleuronectes americanus. PLoS ONE 7:e47047. https://doi.org/10.1371/journ al.pone. 0047047
Mistry N, Drobni P, Näslund J, Sunkari VG, Jenssen H, Evander M (2007) The anti-papillomavirus activity of human and bovine lactoferricin. Antiviral Res 75:258-265. https://doi. org/10.1016/j.antiviral.2007.03.012

Monteiro JMC, Oliveira MD, Dias RS, Nacif-Marçal L, Feio RN, Ferreira SO, Oliveira LL, Silva CC, Paula SO (2018) The antimicrobial peptide HS-1 inhibits dengue virus infection. Virology 514:79-87. https://doi.org/10.1016/j.virol.2017.11.009

Moreno M, Giralt E (2015) Three valuable peptides from bee and wasp venoms for therapeutic and biotechnological use: melittin, apamin and mastoparan. Toxins 7:1126-1150. https://doi. org/10.3390/toxins 7041126

Nevola L, Giralt E (2015) Modulating protein-protein interactions: the potential of peptides. Chem Commun (Camb) 51:3302-3315. https://doi.org/10.1039/c4cc08565e

Newton M, Cabezas-Perusse Y, Tong CL, Seelig B (2019) In vitro selection of peptides and proteins-advantages of mRNA display. ACS Synth Biol 9:181-190. https://doi.org/10.1021/acssy nbio.9b00419

Oku N, Gustafson KR, Cartner LK, Wilson JA, Shigematsu N, Hess S, Pannell LK, Boyd MR, McMahon JB (2004) Neamphamide A, a new HIV-inhibitory depsipeptide from the papua new guinea marine sponge Neamphius huxleyi. J Nat 67:1407-1411. https ://doi.org/10.1021/np040003f

Ozawa M, Ohashi K, Onuma M (2005) Identification and characterization of peptides binding to newcastle disease virus by phage display. J Vet Med Sci 67:1237-1241. https://doi.org/10.1292/ jvms.67.1237

Panya A, Yongpitakwattana P, Budchart P, Sawasdee N, Krobthong S, Paemanee A, Roytrakul S, Rattanabunyong S, Choowongkomon K, Yenchitsomanus P (2019) Novel bioactive peptides demonstrating anti-dengue virus activity isolated from the Asian medicinal plant Acacia Catechu. Chem Biol Drug Des 93:100-109. https://doi.org/10.1111/cbdd.13400

Patching SG (2014) Surface plasmon resonance spectroscopy for characterization of membrane protein-ligand interactions and its potential for drug discovery. Biochim Biophys Acta 1838:43-55. https://doi.org/10.1016/j.bbamem.2013.04.028

Peng B, Chen H, Tan Y, Jin M, Chen H, Guo A (2006) Identification of one peptide which inhibited infectivity of avian infectious bronchitis virus in vitro. Sci China C 49:8. https://doi.org/10.1007/ s11427-006-0158-7

Plaza A, Gustchina E, Baker HL, Kelly M, Bewley CA (2007) Mirabamides A-D, Depsipeptides from the Sponge Siliquariaspongia mirabilis that inhibit HIV-1 Fusion. J Nat Prod 70:1753-1760. https://doi.org/10.1021/np070306k

Plaza A, Bifulco G, Keffer JL, Lloyd JR, Baker HL, Bewley CA (2009) Celebesides A-C and theopapuamides B-D, depsipeptides from an Indonesian sponge that inhibit HIV-1 entry. J Org Chem 74:504-512. https://doi.org/10.1021/jo802232u

Plaza A, Bifulco G, Masullo M, Lloyd JR, Keffer JL, Colin PL, Hooper JN, Bell LJ, Bewley CA (2010) Mutremdamide A and koshikamides $\mathrm{C}-\mathrm{H}$, peptide inhibitors of HIV-1 entry from different Theonella species. J Org Chem 75:4344-4355. https://doi. org/10.1021/jo100076g

Quinones-Mateu ME, Lederman MM, Feng Z, Chakraborty B, Weber J, Rangel HR, Marotta ML, Mirza M, Jiang B, Kiser P, Medvik K (2003) Human epithelial beta-defensins 2 and 3 inhibit HIV-1 replication. AIDS 17:F39-F48. https://doi.org/10.1097/01. aids.0000096878.73209.4f

Qureshi A, Thakur N, Himani T, Kumar M (2013) AVPdb: a database of experimentally validated antiviral peptides targeting medically important viruses. Nucl Acids Res 42:D1147-D1153. https://doi. org/10.1093/nar/gkt1191

Rajik M, Jahanshiri F, Omar AR, Ideris A, Hassan SS, Yusoff K (2009) Identification and characterisation of a novel anti-viral peptide 
against avian influenza virus H9N2. Virol J 6:74. https://doi. org/10.1186/1743-422X-6-74

Ramanujam P, Tan WS, Nathan S, Yusoff K (2002) Novel peptides that inhibit the propagation of Newcastle disease virus. Arch Virol 147:981-993. https://doi.org/10.1007/s00705-001-0778-y

Rashid MA, Gustafson KR, Cartner LK, Shigematsu N, Pannell LK, Boyd MR (2001) Microspinosamide, a new HIV-inhibitory cyclic depsipeptide from the marine sponge Sidonops microspinosa. J Nat Prod 64:117-121. https://doi.org/10.1021/np0002379

Rider TH, Zook CE, Boettcher TL, Wick ST, Pancoast JS, Zusman BD (2011) Broad-spectrum antiviral therapeutics. PLoS ONE 6:e22572. https://doi.org/10.1371/journal.pone.0022572

Robinson WE, McDougall B, Tran D, Selsted ME (1998) Anti-HIV-1 activity of indolicidin, an antimicrobial peptide from neutrophils. J Leukoc Biol 63:94-100. https://doi.org/10.1002/jlb.63.1.94

Rogers MS, Cryan LM, Habeshian KA, Bazinet L, Caldwell TP, Ackroyd PC, Christensen KA (2012) A FRET-based high throughput screening assay to identify inhibitors of anthrax protective antigen binding to capillary morphogenesis gene 2 protein. PLoS ONE 7:e39911. https://doi.org/10.1371/journal.pone.0039911

Rothan HA, Abdulrahman AY, Sasikumer PG, Othman S, Abd Rahman N, Yusof R (2012) Protegrin-1 inhibits dengue NS2B-NS3 serine protease and viral replication in MK2 cells. J Biomed Biotechnol 2012:1-6. https://doi.org/10.1155/2012/251482

Rothan HA, Bahrani H, Rahman NA, Yusof R (2014) Identification of natural antimicrobial agents to treat dengue infection: in vitro analysis of latarcin peptide activity against dengue virus. BMC Microbiol 14:1-10. https://doi.org/10.1186/1471-2180-14-140

Salvatore M, García-Sastre A, Ruchala P, Lehrer RI, Chang T, Klotman ME (2007) $\alpha$-defensin inhibits influenza virus replication by cell-mediated mechanism(s). J Infect Dis 196:835-843. https ://doi.org/10.1086/521027

Sample CJ, Hudak KE, Barefoot BE, Koci MD, Wanyonyi MS, Abraham S, Staats HF, Ramsburg EA (2013) A mastoparan-derived peptide has broad-spectrum antiviral activity against enveloped viruses. Peptides 48:96-105. https://doi.org/10.1016/j.pepti des.2013.07.014

Sen N, Kanitkar TR, Roy AA, Soni N, Amritkar K, Supekar S, Nair S, Singh G, Madhusudhan M (2019) Predicting and Designing therapeutics against the Nipah virus. PLoS Negl Trop Dis 13:e0007419. https://doi.org/10.1371/journal.pntd.0007419

Sencanski M, Radosevic D, Perovic V, Gemovic B, Stanojevic M, Veljkovic N, Glisic S (2015) Natural products as promising therapeutics for treatment of influenza disease. Curr Pharm Des 21:5573-5588. https://doi.org/10.2174/13816128216661510021 13426

Shah NB, Duncan TM (2014) Bio-layer interferometry for measuring kinetics of protein-protein interactions and allosteric ligand effects. J Vis Exp 18:e51383. https://doi.org/10.3791/51383

Shin HJ, Rashid MA, Cartner LK, Bokesch HR, Wilson JA, McMahon JB, Gustafson KR (2015) Stellettapeptins A and B, HIV-inhibitory cyclic depsipeptides from the marine sponge Stelletta sp. Tetrahedron Lett 56:4215-4219. https://doi.org/10.1016/j.tetle t.2015.05.058

Skalickova S, Heger Z, Krejcova L, Pekarik V, Bastl K, Janda J, Kostolansky F, Vareckova E, Zitka O, Adam V, Kizek R (2015) Perspective of use of antiviral peptides against influenza virus. Viruses 7:5428-5442. https://doi.org/10.3390/v7102883

Sørensen OE, Follin P, Johnsen AH et al (2001) Human cathelicidin, hCAP-18, is processed to the antimicrobial peptide LL-37 by extracellular cleavage with proteinase 3. Blood 97:3951-3959. https://doi.org/10.1182/blood.v97.12.3951

Sousa FH, Casanova V, Findlay F, Stevens C, Svoboda P, Pohl J, Proudfoot L, Barlow PG (2017) Cathelicidins display conserved direct antiviral activity towards rhinovirus. Peptides 95:76-83. https:// doi.org/10.1016/j.peptides.2017.07.013
Sun EC, Ma JN, Liu NH, Yang T, Zhao J, Geng HW, Wang LF, Qin YL, Bu ZG, Yang YH, Lunt RA, Wang LF, Wu DL (2011) Identification of two linear B-cell epitopes from West Nile virus NS1 by screening a phage-displayed random peptide library. BMC Microbiol 11:160. https://doi.org/10.1186/1471-2180-11-160

Tang Y, Zeng X, Liang J (2010) Surface plasmon resonance: an introduction to a surface spectroscopy technique. J Chem Educ 87:742-746. https://doi.org/10.1021/ed100186y

Teissier E, Penin F, Pécheur EI (2011) Targeting cell entry of enveloped viruses as an antiviral strategy. Molecules 16:221-250. https:// doi.org/10.3390/molecules 16010221

Tennyson RL, Walker SN, Ikeda T, Harris RS, McNaughton BR (2018) Evaluation of sequence variability in HIV-1 gp41 C-peptide helix-grafted proteins. Bioorg Med Chem 26:1220-1224. https ://doi.org/10.1016/j.bmc.2017.07.064

Tripathi S, Wang G, White M, Qi L, Taubenberger J, Hartshorn KL (2015) Antiviral activity of the human cathelicidin, LL-37, and derived peptides on seasonal and pandemic influenza A viruses. PLoS ONE 10:1-17. https://doi.org/10.1371/journal.pone.01247 06

Van der Strate BWA, Beljaars L, Molema G, Harmsen MC, Meijer DKF (2001) Antiviral activities of lactoferrin. Antiviral Res 52:225-239. https://doi.org/10.1016/s0166-3542(01)00195-4

Wachinger M, Kleinschmidt A, Winder D, von Pechmann N, Ludvigsen A, Neumann M, Holle R, Salmons B, Erfle V, Brack-Werner R (1998) Antimicrobial peptides melittin and cecropin inhibit replication of human immunodeficiency virus 1 by suppressing viral gene expression. J Gen Virol 79:731-740. https://doi. org/10.1099/0022-1317-79-4-731

Wang H, Liu R (2011) Advantages of mRNA display selections over other selection techniques for investigaiu Rtion of protein-protein interactions. Expert Rev Proteomic 8:335-346. https://doi. org/10.1586/epr.11.15

Wang CKL, Colgrave ML, Gustafson KR, Ireland DC, Goransson U, Craik DJ (2008) Anti-HIV cyclotides from the Chinese medicinal herb Viola yedoensis. J Nat Prod 71:47-52. https://doi. org/10.1021/np070393g

Wang W, Liu Y, Zu X, Jin R, Xiao G (2011) Blocking peptides against HBV: PreS1 protein selected from a phage display library. Biochem Biophys Res Commun 412:633-637. https://doi. org/10.1016/j.bbrc.2011.08.014

Wang WY, Wong JH, Ip DT, Wan DC, Cheung RC, Ng TB (2016) Bovine lactoferrampin, human lactoferricin, and lactoferrin 1-11 inhibit nuclear translocation of HIV integrase. Appl Biochem Biotechnol 179:1202-1212. https://doi.org/10.1007/s1201 0-016-2059-y

Wang CK, Shih LY, Chang K (2017) Large-scale analysis of antimicrobial activities in relation to amphipathicity and charge reveals novel characterization of antimicrobial peptides. Molecules 22:2037. https://doi.org/10.3390/molecules22112037

Wartchow CA, Podlaski F, Li S, Rowan K, Zhang X, Mark D, Huang KS (2011) Biosensor-based small molecule fragment screening with biolayer interferometry. J Comput Aided Mol Des 25:669676. https://doi.org/10.1007/s10822-011-9439-8

Wei J, Hameed M, Wang X, Zhang J, Guo S, Anwar MN, Pang L, Liu K, Li B, Shao D, Qiu Y (2019) Antiviral activity of phage display-selected peptides against Japanese encephalitis virus infection in vitro and in vivo. Antiviral Res 174:104673. https:// doi.org/10.1016/j.antiviral.2019.104673

Weidmann J, Craik DJ (2016) Discovery, structure, function, and applications of cyclotides: circular proteins from plants. J Exp Bot 67:4801-4812. https://doi.org/10.1093/jxb/erw210

Wu Z, Cocchi F, Gentles D, Ericksen B, Lubkowski J, DeVico A, Lehrer RI, Lu W (2005) Human neutrophil $\alpha$-defensin 4 inhibits HIV-1 infection in vitro. FEBS Lett 579:162-166. https://doi. org/10.1016/j.febslet.2004.11.062 
Wu SJ, Luo J, O’Neil KT, Kang J, Lacy ER, Canziani G, Baker A, Huang M, Tang QM, Raju TS, Jacobs SA (2010) Structure-based engineering of a monoclonal antibody for improved solubility. Protein Eng Des Sel 23:643-651. https://doi.org/10.1093/prote in/gzq037

Wu D, Li G, Qin C, Ren X (2011) Phage displayed peptides to avian H5N1 virus distinguished the virus from other viruses. PLoS ONE 6:e23058. https://doi.org/10.1371/journal.pone.0023058

Yan R, Zhao Z, He Y, Wu L, Cai D, Hong W, Wu Y, Cao Z, Zheng C, Li W (2011) A new natural $\alpha$-helical peptide from the venom of the scorpion Heterometrus petersii kills HCV. Peptides 32:11-19. https://doi.org/10.1016/j.peptides.2010.10.008

Yin L, Luo Y, Liang B, Wang F, Du M, Petrenko VA, Qiu HJ, Liu A (2014) Specific ligands for classical swine fever virus screened from landscape phage display library. Antivir Res 109:68-71. https://doi.org/10.1016/j.antiviral.2014.06.012

Yu D, Ding X, Liu Z, Wu X, Zhu Y, Wei H, Chong H, Cui S, He Y (2018) Molecular mechanism of HIV-1 resistance to sifuvirtide, a clinical trial-approved membrane fusion inhibitor. J Biol Chem 293:12703-12718. https://doi.org/10.1074/jbc.ra118.003538

Yuan L, Zhang S, Peng J, Li Y, Yang Q (2019) Synthetic surfactin analogues have improved anti-PEDV properties. PLoS ONE 14:e0215227. https://doi.org/10.1371/journal.pone.0215227

Zahnd C, Amstutz P, Plückthun A (2007) Ribosome display: selecting and evolving proteins in vitro that specifically binds to a target. Nat Methods 4:269-279. https://doi.org/10.1038/nmeth1003

Zampella A, D'Auria MV, Paloma LG, Casapullo A, Minale L, Debitus C, Henin Y (1996) Callipeltin A, an anti-hiv cyclic depsipeptide from the new caledonian lithistida sponge Callipelta sp. J Am Chem Soc 118:6202-6209. https://doi.org/10.1021/ja954287p

Zampella A, Sepe V, Luciano P, Bellotta F, Monti MC, D'Auria MV, Jepsen T, Petek S, Adeline MT, Laprévôte O, Aubertin AM
(2008) Homophymine A, an anti-HIV cyclodepsipeptide from the sponge Homophymia sp. J Org Chem 73(14):5319-5327. https://doi.org/10.1021/jo800583b

Zeng Z, Zhang R, Hong W, Cheng Y, Wang H, Lang Y, Ji Z, Wu Y, Li W, Xie Y, Cao Z (2018) Histidine-rich modification of a scorpion-derived peptide improves bioavailability and inhibitory activity against HSV-1. Theranostics 8:199-211. https://doi. org/10.7150/thno.21425

Zhan S, Aweya JJ, Wang F, Yao D, Zhong M, Chen J, Li S, Zhang Y (2018) Litopenaeus vannamei attenuates white spot syndrome virus replication by specific antiviral peptides generated from hemocyanin. Dev Comp Immunol 91:50-61. https://doi. org/10.1016/j.dci.2018.10.005

Zhang LJ, Gallo RL (2016) Antimicrobial peptides. Curr Biol 26:R14R19. https://doi.org/10.1016/j.cub.2015.11.017

Zhang Q, Wang Y, Ji Q, Gu J, Liu S, Feng X, Sun C, Li Y, Lei L (2012) Selection of antiviral peptides against mink enteritis virus using a phage display peptide library. Curr Microbiol 66:379-384. https ://doi.org/10.1007/s00284-012-0284-3

Zhao Z, Hong W, Zeng Z, Wu Y, Hu K, Tian X, Li W, Cao Z (2012) Mucroporin-M1 inhibits hepatitis B virus replication by activating the mitogen-activated protein kinase (MAPK) pathway and down-regulating HNF4 $\alpha$ in vitro and in vivo. J Biol Chem 287:30181-30190. https://doi.org/10.1074/jbc.m112.370312

Zu X, Liu Y, Wang S, Jin R, Zhou Z, Liu H, Gong R, Xiao G, Wang W (2014) Peptide inhibitor of Japanese encephalitis virus infection targeting envelope protein domain III. Antiviral Res 104:7-14. https://doi.org/10.1016/j.antiviral.2014.01.011

Publisher's Note Springer Nature remains neutral with regard to jurisdictional claims in published maps and institutional affiliations. 